IZA DP No. 7958

The Own-Wage Elasticity of Labor Demand:

A Meta-Regression Analysis

Andreas Lichter

Andreas Peichl

Sebastian Siegloch

February 2014 


\title{
The Own-Wage Elasticity of Labor Demand: A Meta-Regression Analysis
}

\author{
Andreas Lichter \\ IZA and University of Cologne \\ Andreas Peichl \\ ZEW, University of Mannheim, IZA, ISER and CESifo \\ Sebastian Siegloch \\ IZA and ZEW
}

Discussion Paper No. 7958
February 2014

IZA

P.O. Box 7240

53072 Bonn

Germany

Phone: +49-228-3894-0

Fax: +49-228-3894-180

E-mail: iza@iza.org

Any opinions expressed here are those of the author(s) and not those of IZA. Research published in this series may include views on policy, but the institute itself takes no institutional policy positions. The IZA research network is committed to the IZA Guiding Principles of Research Integrity.

The Institute for the Study of Labor (IZA) in Bonn is a local and virtual international research center and a place of communication between science, politics and business. IZA is an independent nonprofit organization supported by Deutsche Post Foundation. The center is associated with the University of Bonn and offers a stimulating research environment through its international network, workshops and conferences, data service, project support, research visits and doctoral program. IZA engages in (i) original and internationally competitive research in all fields of labor economics, (ii) development of policy concepts, and (iii) dissemination of research results and concepts to the interested public.

IZA Discussion Papers often represent preliminary work and are circulated to encourage discussion. Citation of such a paper should account for its provisional character. A revised version may be available directly from the author. 
IZA Discussion Paper No. 7958

February 2014

\section{ABSTRACT}

\section{The Own-Wage Elasticity of Labor Demand: A Meta-Regression Analysis*}

Firms' labor demand responses to wage changes are of key interest in empirical research and policy analysis. However, despite extensive research, estimates of labor demand elasticities remain subject to considerable heterogeneity. In this paper, we conduct a comprehensive meta-regression analysis to re-assess the empirical literature on labor demand elasticities. Building on 942 elasticity estimates from 105 different studies, we identify sources of variation in the absolute value of this elasticity. Heterogeneity due to the theoretical and empirical specification of the labor demand model, different datasets used or sectors and countries considered explains more than $80 \%$ of the variation in the estimates. We further find substantial evidence for the presence of publication selection bias, as estimates of the own-wage elasticity of labor demand are upwardly inflated.

JEL Classification: J23, C10, C83

Keywords: $\quad$ labor demand, wage elasticity, meta-analysis

Corresponding author:

Andreas Peichl

ZEW

$\mathrm{L} 7,1$

68161 Mannheim

Germany

E-mail: peichl@zew.de

\footnotetext{
* We would like to thank David Autor, David Card and Daniel Hamermesh as well as seminar and conference participants in Bonn (IZA) and at the MAER-Net Colloquium 2013 for helpful comments and suggestions on an earlier draft. The authors thank Daniela Geppert for valuable research assistance.
} 


\section{Introduction}

The question of how individuals and firms adapt their behavior in response to policy changes is one of the most investigated topics in empirical labor economics. In this context, firms' wage elasticities of labor demand are of key interest as the effectiveness of labor market reforms crucially depends on the firms' labor demand responses to wage changes (Hamermesh, 1993). Besides this, own- and cross-wage elasticities of labor demand for differently-skilled labor also serve as key parameters when assessing structural changes in production due to skill-biased technological and organizational change, as well as when evaluating the effectiveness and optimal size of minimum wages.

Furthermore, labor demand elasticities also play a key role in many other fields besides labor economics. Firms' labor demand responses to wage rate changes have gained increasing attention in public finance, with own-wage elasticities of labor demand serving as an important input in optimal tax models of individuals and firms (Jacquet et al., 2012; Riedel, 2011), as well as determining the deadweight loss due to taxation. In international economics, the wage elasticity of labor demand serves as an important parameter in theoretical models of international trade (Rauch and Trindade, 2003), as well as an indicator when assessing the effects of globalization on the volatility of employment and wages (Rodrik, 1997). Moreover, estimates of the wage elasticity of labor demand are used to calibrate macro and computable general equilibrium (CGE) models in various fields - typically using "guestimated" elasticities (Boeters and Savard, 2013).

The enormous number of studies devoted to the estimation of firms' labor demand responses to wage changes reflects the importance of this parameter. Despite this, a consensus on the genuine value of this parameter has not yet been achieved. Fuchs et al. (1998) find that beliefs about the true value of this elasticity are widely dispersed among labor and public economists. Estimates of the own-wage elasticity of labor demand differ substantially, even for the same country and time period 1$]$

\footnotetext{
${ }^{1}$ For instance, estimates of the constant-output own-wage elasticity for Germany range from -0.100 (Koebel, 2002), over -0.307 (Muendler and Becker, 2010) to -0.881 (Barba Navaretti et al., 2003 .
} 
In order to narrow down the "true" size of the labor demand elasticity, we thus conduct a comprehensive meta-regression analysis based on 942 elasticity estimates collected from 105 micro-level labor demand studies. This allows us to explicitly analyze sources of heterogeneity in the estimates of the elasticity. In particular, we assess the consistency with respect to the theory (total vs. constant-output elasticities), and the timing (short- vs. intermediate- vs. long-run elasticities). In addition, we also consider the effects of the researcher's empirical specification of the labor demand model, given that the choice of the empirical model and whether to instrument the wage variable might significantly affect the absolute value of the elasticity. Likewise, different sources (administrative vs. survey) and types (panel vs. cross-sectional and time-series) of data, as well as the observational level (industry- vs. firm-level) of the dataset could contribute to the heterogeneity in the estimates. We also control for worker and industry characteristics as firm's demand for unskilled labor or workers on atypical contracts might be more elastic than the demand for high-skilled workers on open-ended contracts. Likewise, elasticities of labor demand are likely to differ across sectors, with some being more labor intensive than others. Heterogeneity in the estimates could also be explained by changes in firms' labor demand responsiveness over time, as accelerating globalization and technological change might have rendered labor demand more elastic. Lastly, as labor market institutions are likely to affect firm behavior and its labor demand decisions, own-wage elasticities of labor demand are expected to differ across countries.

Besides determining sources of heterogeneity in the own-wage elasticity of labor demand, our meta-regression analysis allows us to explicitly address the issue of publication selection (or reporting) bias. In general, the journals' preference to publish statistically significant results (DeLong and Lang, 1992) and economists strong beliefs in particular economic relationships might prompt researchers to select and referees and editors to publish expected empirical results (Card and Krueger, 1995). There is unanimous belief in a negative relationship of real wages and labor demand, and thus a negative own-wage elasticity. This belief has been further shaped by the seminal work of Hamermesh (1993), who reviews the earlier empirical literature on labor demand and concludes that the value of the constant-output own-wage elas- 
ticity of labor demand is bracketed by $[0.15 ; 0.75]$, with his best guess being 0.30 . Researchers might thus be predisposed towards reporting negative and statistically significant elasticities. We explicitly test for the presence of publication selection bias by analyzing the relationship of the estimated parameter and its standard error, which should be insignificant in the absence of publication bias.

By means of our meta-regression analysis, we are able to explain more than $80 \%$ of the variation within our data. Our empirical results back up the underlying theory, with labor demand being less elastic in the short-run than in the intermediateand long-run. Interestingly, differences between total and constant-output elasticities are not captured by reduced-form models of labor demand. With respect to the datasets employed, elasticity estimates obtained from administrative (firm-level) data exceed estimates from survey (industry-level) data in absolute terms. As expected, our results further show that demand for unskilled labor and workers with atypical contracts is particularly responsive to wage rate changes. Moreover, we find significant evidence that labor demand elasticities have increased over time and differ substantially across countries. Strikingly, our results further show strong evidence for substantial publication bias, with estimates of the own-wage elasticity of labor demand being upwardly inflated. Publication bias is found to be particularly strong for estimates of the short-run elasticities and much weaker for estimates based on structural-form models.

The remainder of this paper is structured as follows. In Section 2, we describe our dataset, present important characteristics of the empirical estimates of the ownwage elasticity and identify likely source of heterogeneity. In Section 3.1, we then introduce our meta-regression model and discuss the underlying estimation strategy. We present and discuss our results in Section 3.2, account for publication bias in Section 3.3 and test the sensitivity of our results in Section 3.4 , before Section 4 concludes. 


\section{Sample design and descriptive analysis}

The data for our analysis are obtained by thoroughly scanning the literature on labor demand and related topics. To ensure the comparability of results, our sample of studies published before 1993 comprises those micro-level studies evaluated in Hamermesh (1993) only. Overall, we collect 1560 estimates of the own-wage elasticity of labor demand from 151 studies. However, we discard all estimates without a given or calculable standard error ${ }^{2}$ Here, earlier studies estimating own-wage elasticities by means of a structural-form model of labor demand often provide no standard errors for the respective estimate.$^{3}$ Moreover, standard errors are rarely given for the long-run elasticity of labor demand obtained from dynamic reduced-form models. Overall, the number of elasticity estimates thus reduces to 924, obtained from 105 studies 4

The final sample comprises estimates from studies published between 1980 and 2012 and for 37 different countries. Six studies use aggregate OECD or European data. Following Card et al. (2010), Table A.1 in the Appendix provides detailed information on the distribution of estimates by country and latest publication date.

The overall mean (median) own-wage elasticity of labor demand in our sample is $-0.508(-0.386)$, with a standard deviation of 0.774 . Figure (2) depicts the distribution of the elasticity estimates, with more than $80 \%$ of all estimates lying within the interval of zero to minus one. Moreover, we note that $6.28 \%$ of all own-wage elasticities in our sample are positive and $4.11 \%$ exceed a value of 2 in absolute value. In terms of significance, $28.98 \%$ of all estimates report a t-value smaller than 2 in absolute terms.

\footnotetext{
${ }^{2}$ As shown in Section 3, heteroscedasticity is present in meta-regression models. However, the specific form of heteroscedasticity is given by the estimate's specific standard error and a WLS estimator should be applied.

${ }^{3}$ Usage of empirical techniques designed to calculate standard errors for elasticities obtained from a structural-form model, such as bootstrapping or the delta method, started in the early1990s.

${ }^{4}$ As part of our sensitivity analysis, we provide simple OLS regression results based on the full sample of 1560 estimates. The results are very similar to our baseline results reported in the text.
} 
Figure 1: Distribution of Labor Demand Elasticities

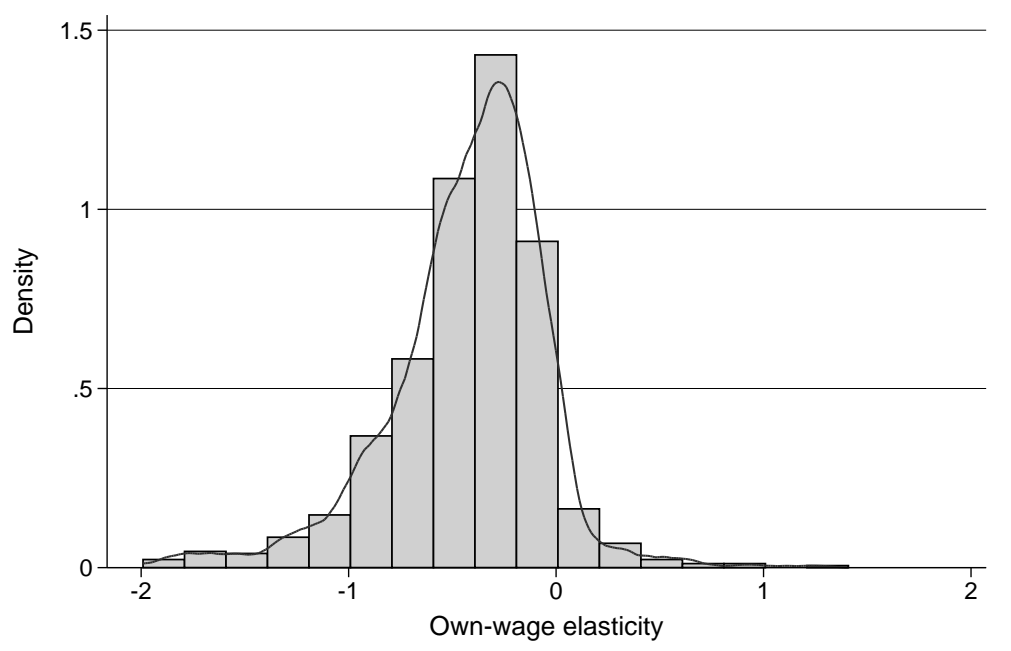

Explanatory variables. Next, we identify likely sources of heterogeneity in the estimates of the own-wage elasticity of labor demand. Following labor demand theory, we distinguish short- from intermediate- and long-run demand for labor. In the short-run, the firm's level of labor is assumed to not fully adjust to the desired level in response to changes in the wage rate. This is due to adjustment costs incurred by institutional regulations, such as employment protection legislation. Likewise, firms' adjustment of capital and material input is limited in the short-run. In the intermediate run, firms are assumed to adjust the level of labor and materials to the optimal level, yet the capital stock has not fully adjusted. In the long-run, full flexibility of the capital stock is assumed. Labor demand theory thus implies that firms' labor demand responses are more limited in the short-run than in the intermediate- and long-run. For the purpose of our empirical analysis we thus classify each estimate in accordance to this definition.5 We further distinguish the total (unconditional) from the constant-output (conditional) elasticity of labor demand. By the fundamental law of demand, the total elasticity exceeds the constant-output elasticity of labor demand in absolute terms, given that it additionally accounts for the negative price elasticity of product demand (Hamermesh, 1993).

In terms of the empirical model of labor demand, we distinguish between

\footnotetext{
${ }^{5}$ Precisely, classification follows by means of the (dis)equilibrium state of labor and capital. Note that labor demand adjusts to the optimal level in a static labor demand model by definition, such that short-run labor demand can be only modeled in a dynamic model of labor demand.
} 
reduced-form and structural-form models. In the latter type of model, regression equations are explicitly linked to theory and own-wage elasticities are calculated from the obtained empirical equation parameters. Within this strand of the literature, different empirical specifications of production and cost functions have been estimated 6 In turn, reduced-form models are normally based on log-linear specifications of unconditional and conditional labor demand models. These models are more flexible with respect to the variables included and coefficients are directly interpretable as elasticities.

Identification of labor demand parameters often rests on the assumption that wages are unaffected by demand. Hamermesh (1993) argues that the wage rate can be considered exogenous from an individual employer's perspective, who faces perfectly elastic labor supply. However, as this assumption is subject to criticism and less likely to hold for industry- or economy-wide labor demand, a considerable share of papers published over the last years has instrumented the wage rate. In our meta-regression analysis, we thus analyze whether instrumenting the wage rate affects the absolute value of the own-wage elasticity of labor demand.

Heterogeneity in the estimates is possibly also due to differences in the datasets used. In contrast to cross-sectional or time-series datasets, panel data allows researchers to explicitly account for firm- or industry-fixed effects. We thus investigate whether cross-sectional and time-series data estimates differ from panel data estimates, as well as whether accounting for unit-fixed effects affects the estimate of the own-wage elasticity of labor demand. Likewise, we test for differences in the own-wage elasticity due to the data source (administrative or survey data) or observational level (firm or industry-level data).

We further assume labor demand to be worker- and sector-specific. It is widely believed that firms' demand for low-skilled labor is more responsive to changes in the wage rate than the demand for high-skilled or medium-skilled workers, as low-skilled tasks might be easily substituted by capital or outsourced to low-income countries. In our meta-regression analysis, we thus distinguish between low-skilled, high-skilled

\footnotetext{
${ }^{6}$ See Diewert and Wales (1987) or Koebel et al. (2003) for empirical evaluations of different cost functions.
} 
and overall demand for labor $]^{7}$ Likewise, we test whether firms' demand for female labor and for workers with atypical contracts is more elastic than for the average worker. Sectoral differences in the demand for labor might also explain differences in the own-wage elasticity of labor demand, as some sectors are more dependent on labor than others. We therefore account for sectoral differences up to the 2-digit level 8

Institutional regulations on employment protection and dismissal may further crucially affect firms' demand for labor. As these regulatory rules differ across countries, we expect to find cross-country differences in the own-wage elasticity of labor demand. In our analysis, we thus explicitly control for the country investigated. Moreover, accelerating international production sharing, global competition and technological advances might have rendered firms' demand for labor more elastic over time. Controlling for the study's year of publication and the mean year of observation in the respective dataset $9^{9}$ we analyze whether this claim is reflected in the meta data.

Descriptive Statistics. Table 1 presents the coded explanatory variables, their respective means and standard deviations. In terms of the theoretical specification of the own-wage elasticity of labor demand, we find that about $80 \%$ of the estimates are intermediate- or long-run elasticities, i.e. reflect firms' responsiveness to wage rate changes in case labor is flexible and adjusts to the desired level. We further find that estimates of the constant-output elasticity of labor demand clearly outnumber the estimates of the total demand elasticity. The literature's focus thus rests on the identification of long-run patterns of factor substitutability. In terms of the empirical specification, we note that the majority of studies estimates reducedform constant-output models of labor demand. In our meta-regression analysis, we

\footnotetext{
${ }^{7}$ We use overall demand as a category due to the fact that many studies do not account for heterogeneous types of labor and obtain elasticities for the overall workforce. Differences in the own-wage elasticity for unskilled and high-skilled labor are thus relative to the overall workforce, which on average represents medium-skilled workers.

${ }^{8}$ Note that many studies focus on one-digit sectors or do not account for sectoral differences at all. Thus, we control for sectoral differences with respect to the overall economy.

${ }^{9}$ Note that in case the elasticity is given for a specific year, the given year is substituted for the mean year of observation.
} 
interact the empirical specification variable with the type of elasticity estimated (constant-output or total elasticity) to allow for variation in the empirical and theoretical specification. Identification of the empirical model primarily rests on the assumption of exogenously given wages, whereas about one-fifth of the estimated elasticities stem from studies that instrument the wage variable. As regards the

Table 1: Explanatory variables for heterogeneity in labor demand elasticities

\section{Specification}

Time period

$\begin{array}{lll}\text { Short-run elasticity } & 0.212 & 0.409 \\ \text { Intermediate-run elasticity } & 0.447 & 0.497 \\ \text { Long-run elasticity } & 0.341 & 0.474 \\ \text { tal demand elasticity (as opposed to: constant-output elasticity) } & 0.209 & 0.407 \\ \text { uctural-form model (as opposed to: reduced-form model) } & 0.365 & 0.482 \\ \text { trumenting wages (as opposed to: exogenous wage) } & 0.180 & 0.384\end{array}$

Instrumenting wages (as opposed to: exogenous wage)

\section{Dataset}

Panel data specification

$$
\text { No panel data }
$$

Panel data/No fixed effects

Panel data/Fixed effects

Administrative data (as opposed to: survey data)

Industry-level data (as opposed to: firm-level data)

$\begin{array}{ll}0.160 & 0.367 \\ 0.111 & 0.315 \\ 0.728 & 0.445 \\ 0.707 & 0.456 \\ 0.604 & 0.489\end{array}$

\section{Workforce}

Skill level

All worker

High-skilled workers

Unskilled workers

Female worker

Atypical employment

$\begin{array}{ll}0.834 & 0.372 \\ 0.063 & 0.243 \\ 0.103 & 0.304 \\ 0.031 & 0.174 \\ 0.063 & 0.243\end{array}$

Industry (One-digit level)

All

$0.350 \quad 0.477$

Manufacturing

Service

0.539

0.499

Construction

$0.043 \quad 0.204$

Other (Mining, Wholesale, Transportation, Electricity \& Water supply)

0.056

0.231

$0.012 \quad 0.109$

Country (Aggregated)

Continental European countries

$0.299 \quad 0.458$

Northern European countries

0.038

0.191

United Kingdom/Ireland

$0.075 \quad 0.263$

Southern European countries

$0.022 \quad 0.146$

USA/Canada

$0.169 \quad 0.375$

Asia

Latin America

0.027

0.162

$0.067 \quad 0.250$

Eastern European countries

0.102

0.302

Africa

$0.028 \quad 0.165$

Aggregate data

0.174

0.380

Mean year of observation

$1989 \quad 9.667$

Mean year of publication 
dataset, $84 \%$ of the elasticities are based on studies using panel data, $86.8 \%$ of which stem from studies that control for unit-fixed effects ${ }^{10}$ Moreover, administrative data sources are used more frequently than survey data sources $(70.7 \%$ to $29.3 \%$ ) for the estimation of own-wage labor demand elasticities in our sample, and slightly more own-wage elasticities of labor demand are based on datasets collected at the industry- rather than firm-level. Considering worker characteristics, we note that the majority of studies in our dataset do not account for heterogeneity in the workforce. However, $6.3 \%$ and $10.3 \%$ of the elasticity estimates explicitly refer to high- and unskilled labor, respectively, such that differences in labor demand across skills can be identified. Likewise, $3.1 \%$ (6.3\%) of the estimates refer to firms' demand for female labor (workers on atypical contracts).

With respect to differences in labor demand across sectors, more than $50 \%$ of the studies focus on the manufacturing sector, with around one-fifth of these studies distinguishing between different industries within the manufacturing sector ${ }^{11}$ Table 1 further shows that few estimates refer to the service and construction sectors, whereas $35 \%$ of the estimates apply for the overall economy.

As indicated before, our dataset covers estimates of the own-wage elasticity of labor demand for 37 countries, as well as estimates based on OECD or aggregate European data, Table A.1 providing the number of estimates obtained for each country. To simplify representation, mean values and standard deviations are given at an aggregate level in Table1, with countries being clustered by geographical location $\sqrt{12}$ We note that a large share of estimates relate to Continental European countries ${ }^{13}$ as well as the US and Canada, amounting to about 50\% of the total estimates. By contrast, only few elasticities estimates are given for Southern European, African or Asian countries. Lastly, we note that the mean year of observation in the datasets

\footnotetext{
${ }^{10}$ Note that $5.1 \%$ and $10.9 \%$ of the estimates are obtained from time-series and cross-sectional data, respectively.

${ }^{11}$ Table A.2 in the Appendix shows the distribution of estimates at the industry level.

${ }^{12}$ Precisely, we group elasticities for Germany, France as well as Belgium, the Netherlands and Luxembourg (BeNeLux) to Continental Europe, whereas Denmark, Norway, Finland and Sweden constitute the Nordic European countries. We further combine the estimates from Italy, Spain, Portugal to Southern Europe and group elasticities from Turkey, Macedonia and the former CIS states to Eastern Europe.

${ }^{13}$ Here, the share of elasticities based on German data is particularly high.
} 
of the primary estimates is 1989 , with a standard deviation of 6.7 years.

\section{Meta-regression analysis}

Having classified likely sources of heterogeneity, we next turn to our meta-regression analysis. In Section 3.1, we briefly present the meta-regression model and estimation technique applied. Section 3.2 provides the meta-regression results and we discuss the various sources of heterogeneity. Subsequently, we explicitly test for the presence of publication selection bias (Section 3.3) and check the sensitivity of our results (Section 3.4).

\subsection{The regression model}

In line with standard meta-regression analysis techniques (Card et al., 2010; Feld and Heckemeyer, 2011), we assume that the $i^{\text {th }}$ estimate of the own-wage elasticity of study $s, \eta_{i s}$, is obtained by means of an econometric technique such that $\eta_{i s}$ varies around its true value $\eta_{0}$ due to sampling error $\left(\epsilon_{i s}\right)$ as well as study- $(\mathbf{X})$ or estimate-specific $(\mathbf{Z})$ heterogeneity as introduced in the previous section:

$$
\eta_{i s}=\eta_{0}+\boldsymbol{\beta} \mathbf{X}_{i}^{\prime}+\boldsymbol{\delta} \mathbf{Z}_{i s}^{\prime}+\epsilon_{i s}
$$

As regards estimation, the meta-regression model given in equation (1) is heteroscedastic: the variance of the individual estimate of the elasticity $\eta_{i s}$ decreases with the size of the underlying sample, which differs between studies and/or within a single study in our sample $\left(V\left(\epsilon_{i s} \mid \mathbf{X}_{i}^{\prime}, \mathbf{Z}_{i s}^{\prime}\right)=\sigma_{\epsilon_{i s}}^{2}\right)$. In meta-regression analysis, the specific form of heteroscedasticity is known, given by means of the standard error of the respective own-wage elasticity. Thus, estimation of equation (1) by Weighted Least Squares (WLS) using the inverse of the error term variances, i.e. the inverse of the squared standard error of the parameter estimate, as analytic weights is more efficient than simple OLS ${ }^{14}$ The standard errors are clustered at the study-level.

\footnotetext{
${ }^{14}$ Stanley and Doucouliagos $(2013)$ show that this estimator is preferable to other standard metaregression estimators. In Section 3.4 , we show the robustness of our results when applying different estimators.
} 


\subsection{Sources of heterogeneity}

Table 2 provides the main results of our meta-regression analysis. In columns 1 to 3 , we separately analyze the different classes of heterogeneity: model specification, type of dataset used and workforce characteristics. Subsequently, we include all classes of heterogeneity in one comprehensive model (column 4). Next, we control for industry- and country-specific effects, as well as the year of publication and the mean year of observation in the primary studies in our most comprehensive regression (column 5).

In line with labor demand theory, the results in column (1) show that firms' demand for labor is more elastic in the intermediate- and long-run compared to the short-run. Institutional rules and/or limited substitutability restrict firms' labor demand adjustment. Nonetheless, differences between the intermediate- and long-run elasticity are small and insignificant. We further find that structural- and reducedform models yield different estimates of the own-wage elasticity. On average, the constant-output elasticity (total-output elasticity) of labor demand is significantly lower (higher) in absolute terms when being derived from a structural-form rather than a reduced-form model. However, estimates of the total and constant-output elasticity do not differ in case of being obtained from a reduced-form model. In terms of identification, our results show that instrumenting the wage rate variable leads to significantly higher estimates of the own-wage elasticity in absolute terms.

Considering data-driven heterogeneity, the results displayed in column (2) show that panel data estimates do not differ from cross-sectional or time-series data. In contrast, we find that estimates of the own-wage elasticity of labor demand are significantly lower for studies relying on administrative rather than survey data sources. Moreover, industry-level estimates exceed firm-level estimates in absolute terms.

In line with our expectations, the results given in column (3) further show that firms' responses to changes in the wage rate are skill-specific. The elasticity of labor demand for unskilled labor is significantly higher than for the overall workforce. Our estimates further indicate that labor demand for high-skilled labor is less elastic compared to the overall workforce, albeit with the differences being statistically 
Table 2: Meta-regression analysis for own-wage labor demand elasticities

\begin{tabular}{|c|c|c|c|c|c|}
\hline Model & $(1)$ & $(2)$ & $(3)$ & $(4)$ & $(5)$ \\
\hline Constant & $\begin{array}{c}-0.044^{*} \\
(0.025)\end{array}$ & $\begin{array}{l}-0.224^{* * *} \\
(0.060)\end{array}$ & $\begin{array}{l}-0.136^{* * *} \\
(0.047)\end{array}$ & $\begin{array}{l}-0.026 \\
(0.089)\end{array}$ & $\begin{array}{l}-0.428^{* *} \\
(0.183)\end{array}$ \\
\hline \multicolumn{6}{|l|}{ Specification } \\
\hline \multicolumn{6}{|l|}{ Time period (omitted: Short-run) } \\
\hline Intermediate-run & $\begin{array}{l}-0.274^{* * *} \\
(0.082)\end{array}$ & & & $\begin{array}{l}-0.212^{* * *} \\
(0.068)\end{array}$ & $\begin{array}{l}-0.113^{* * *} \\
(0.042)\end{array}$ \\
\hline Long-run & $\begin{array}{l}-0.330^{* * *} \\
(0.059)\end{array}$ & & & $\begin{array}{l}-0.266^{* * *} \\
(0.063)\end{array}$ & $\begin{array}{l}-0.127^{* * *} \\
(0.039)\end{array}$ \\
\hline \multicolumn{6}{|c|}{ Labor demand model (omitted: Conditional/Reduced-form) } \\
\hline Conditional/Structural-form & $\begin{array}{l}0.198^{* *} \\
(0.076)\end{array}$ & & & $\begin{array}{l}0.068 \\
(0.079)\end{array}$ & $\begin{array}{l}-0.047 \\
(0.070)\end{array}$ \\
\hline Unconditional/Reduced-form & $\begin{array}{l}-0.005 \\
(0.057)\end{array}$ & & & $\begin{array}{l}-0.020 \\
(0.071)\end{array}$ & $\begin{array}{l}-0.018 \\
(0.052)\end{array}$ \\
\hline Unconditional/Structural-form & $\begin{array}{l}-0.127^{* *} \\
(0.056)\end{array}$ & & & $\begin{array}{l}-0.300^{* * *} \\
(0.110)\end{array}$ & $\begin{array}{l}-0.137 \\
(0.110)\end{array}$ \\
\hline Instrumenting wages & $\begin{array}{l}-0.164^{* * *} \\
(0.034)\end{array}$ & & & $\begin{array}{l}-0.096^{* *} \\
(0.041)\end{array}$ & $\begin{array}{l}0.029 \\
(0.035)\end{array}$ \\
\hline \multicolumn{6}{|l|}{ Dataset } \\
\hline \multicolumn{6}{|l|}{ Panel data specification (omitted: No panel data) } \\
\hline Panel data/No unit-fixed effects & & $\begin{array}{l}0.034 \\
(0.087)\end{array}$ & & $\begin{array}{l}-0.043 \\
(0.092)\end{array}$ & $\begin{array}{l}-0.184 \\
(0.115)\end{array}$ \\
\hline Panel data/Unit-fixed effects & & $\begin{array}{l}-0.020 \\
(0.052)\end{array}$ & & $\begin{array}{l}-0.104 \\
(0.082)\end{array}$ & $\begin{array}{l}-0.162 \\
(0.112)\end{array}$ \\
\hline Administrative data & & $\begin{array}{l}0.198^{* * *} \\
(0.049)\end{array}$ & & $\begin{array}{l}0.120^{* * *} \\
(0.038)\end{array}$ & $\begin{array}{l}0.231^{* * *} \\
(0.079)\end{array}$ \\
\hline Industry level data & & $\begin{array}{c}-0.087^{*} \\
(0.052)\end{array}$ & & $\begin{array}{l}-0.030 \\
(0.045)\end{array}$ & $\begin{array}{c}-0.086^{*} \\
(0.051)\end{array}$ \\
\hline \multicolumn{6}{|l|}{ Workforce characteristics } \\
\hline \multicolumn{6}{|l|}{ Skill level (omitted: All workers) } \\
\hline High-skilled workers & & & $\begin{array}{l}0.068 \\
(0.067)\end{array}$ & $\begin{array}{l}-0.015 \\
(0.111)\end{array}$ & $\begin{array}{l}0.018 \\
(0.075)\end{array}$ \\
\hline Low-skilled workers & & & $\begin{array}{l}-0.323^{* * *} \\
(0.080)\end{array}$ & $\begin{array}{l}-0.142^{* *} \\
(0.063)\end{array}$ & $\begin{array}{l}-0.207^{* * *} \\
(0.035)\end{array}$ \\
\hline Demand for female workers & & & $\begin{array}{l}-0.079 \\
(0.055)\end{array}$ & $\begin{array}{l}-0.079 \\
(0.062)\end{array}$ & $\begin{array}{l}-0.173^{* * *} \\
(0.030)\end{array}$ \\
\hline Atypical employment & & & $\begin{array}{l}-0.704^{* * *} \\
(0.055)\end{array}$ & $\begin{array}{l}-0.652^{* * *} \\
(0.067)\end{array}$ & $\begin{array}{l}-0.551^{* * *} \\
(0.047)\end{array}$ \\
\hline Estimates' mean year of observation (centralized) & & & & & $\begin{array}{l}-0.008^{*} \\
(0.004)\end{array}$ \\
\hline Industry dummy variables & No & No & No & No & Yes \\
\hline Year of publication dummy variables & No & No & No & No & Yes \\
\hline Country dummy variables & No & No & No & No & Yes \\
\hline No. of observations & 924 & 924 & 924 & 924 & 924 \\
\hline Adjusted R-Squared & 0.414 & 0.211 & 0.175 & 0.557 & 0.836 \\
\hline
\end{tabular}

Note: Standard errors (in parentheses) are clustered at the study level. Significance levels are $0.1(*), 0.05\left({ }^{* *}\right)$ and $0.01(* * *)$.

insignificant. Conditioning on worker-specific variables only, the results given in column (3) further show no differential demand for female labor and more elastic demand for atypical than overall employment.

Following the individual assessment of each source of heterogeneity, we next 
combine all three dimensions of heterogeneity in one regression. The results detailed in column (4) show that previous findings do not change much when jointly evaluating all three dimensions. We thus further include industry and country dummy variables in our regression, given that industries differ in terms of labor intensity and cross-national differences in labor market institutions are likely to affect firms' labor demand behavior. Moreover, we analyze whether labor demand has become more elastic over the periods covered by our data. To identify shifts in the own-wage elasticity of labor demand over time, we control for the mean year of observation underlying the particular point estimate, as well as the study's year of publication.

Looking at column (5), we first note that we are able to explain more than $80 \%$ of the variation of the own-wage elasticity estimates, with the adjusted RSquared having increased to 0.84. Furthermore, including the additional control variables only affects our previous statements to a limited extent. Differences in the own-wage elasticity estimates due to the empirical model applied turn insignificant and instrumenting the wage variable does not affect the estimate. Given that the debate on the identification of labor demand models is more recent, it is unsurprising that the difference turns insignificant when controlling for the year of publication. Analyzing the newly added regressors, we find that the own-wage elasticity of labor demand increases with the mean year of observation in the underlying data. Our meta-regression results thus show that labor demand has become more elastic over time.

Figure 2: Industry- and country-specific own-wage elasticities
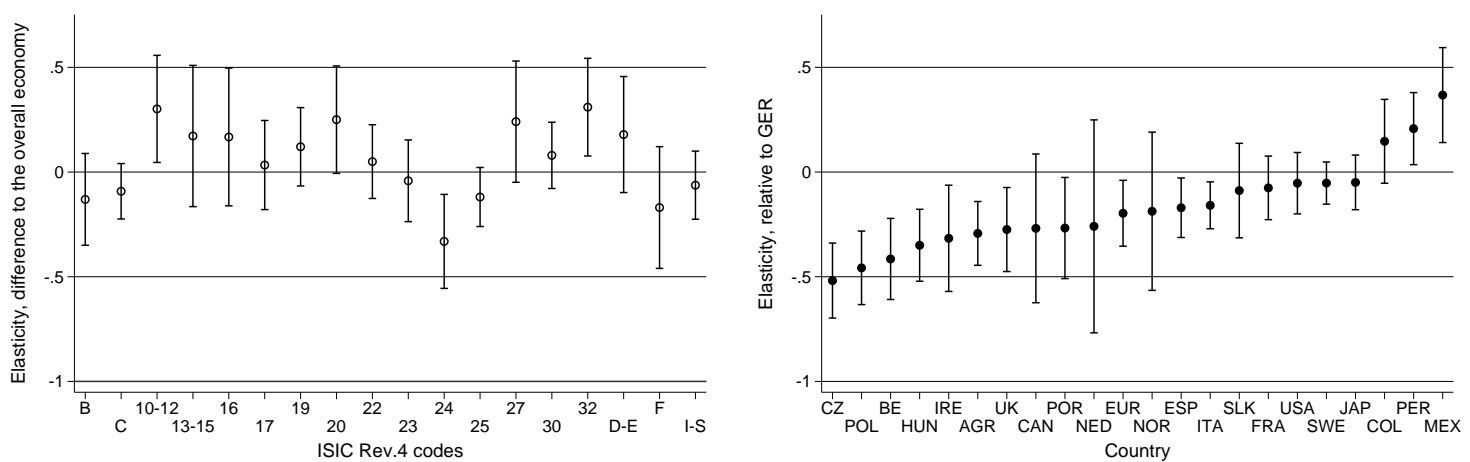

Note: Industry codes refer to Mining (B); Manufacturing (C); Manufacture of food, beverages, tobacco (10-12); Manufacture of textiles, apparel, leather (13-15); Manufacture of wood \& wood products (16); Manufacture of paper \& paper products (17); Manufacture of petroleum (19); Manufacture of chemicals \& chemical products (20); Manufacture of rubber \& plastic products (22); Manufacture of non-metallic mineral products (23); Manufacture of basic metals (24); Manufacture of metal products (25); Manufacture of electrical equipment (27); Manufacture of transport equipment (30); Other manufacturing (32); Electricity, gas and water supply (D-E); Construction (F); Service (I-S) 
Considering industry- and country-specific labor demand, Figure 2 shows sizable and significant differences in the own-wage elasticity of labor demand across industries and countries. In detail, the left panel of Figure 2 shows differences in the industry-specific own-wage elasticity with respect to the own-wage elasticity of labor demand for all sectors $\sqrt{15}$ For example, we find that labor demand is significantly less elastic in the food, beverages and tobacco industry (isic 10-12) and significantly more elastic in the basic metals industry (isic 24). The right panel of Figure 2 plots the country-specific difference in the own-wage elasticity of labor demand relative to Germany ${ }^{16}$ Our meta-regression results show that own-wage elasticities are significantly higher in absolute terms for the UK and Ireland, as well as many Eastern European countries. In contrast, labor demand is found to be less elastic in Mexico and Peru. However, conditioning on all other sources of heterogeneity, we find no statistically significant differences in the own-wage elasticity of labor demand for Germany and the US.

\subsection{Publication selection bias}

In the second part of our analysis, we evaluate whether publication selection bias is present in the empirical literature on labor demand. As noted in the introduction, journals' tendency to publish statistically significant results and researchers' strong beliefs in particular economic relationships might lead to the reporting and publication of significant results that are in line with expectations.

Identification of publication selection bias rests on the relationship between the estimated coefficient and its standard error (Card and Krueger, 1995; Stanley and Doucouliagos, 2013). If publication bias indeed induces researchers to only report significantly negative own-wage elasticities, we expect to find a negative (positive) relationship between (the absolute value of) the own-wage elasticity and the elasticity's standard error. Researchers who employ small samples and thus face low precision of their estimates need to search harder along different specifications or

\footnotetext{
${ }^{15}$ Note that this graph merely displays the difference in the own-wage elasticity for those industries where estimates were obtained from at least two different studies.

${ }^{16}$ As for the left panel, the presentation is limited to those countries where elasticities are obtained from more than one study.
} 
estimation techniques to find larger estimates that provide statistically significant outcomes (Card and Krueger, 1995). As a result, own-wage elasticities of labor demand might be upwardly inflated.

A common method to detect publication selection bias is the evaluation of a so-called "funnel graph" (Sutton et al., 2000). Here, the own-wage elasticity is plotted against the inverse of the particular standard error. In case no publication bias is present within the literature, the graph is expected to have a funnel shape, i.e. low-precision estimates should be symmetrically distributed at the bottom of the graph. However, the plot shown in Figure 3 displays considerable asymmetry,

Figure 3: Country-specific own-wage elasticities

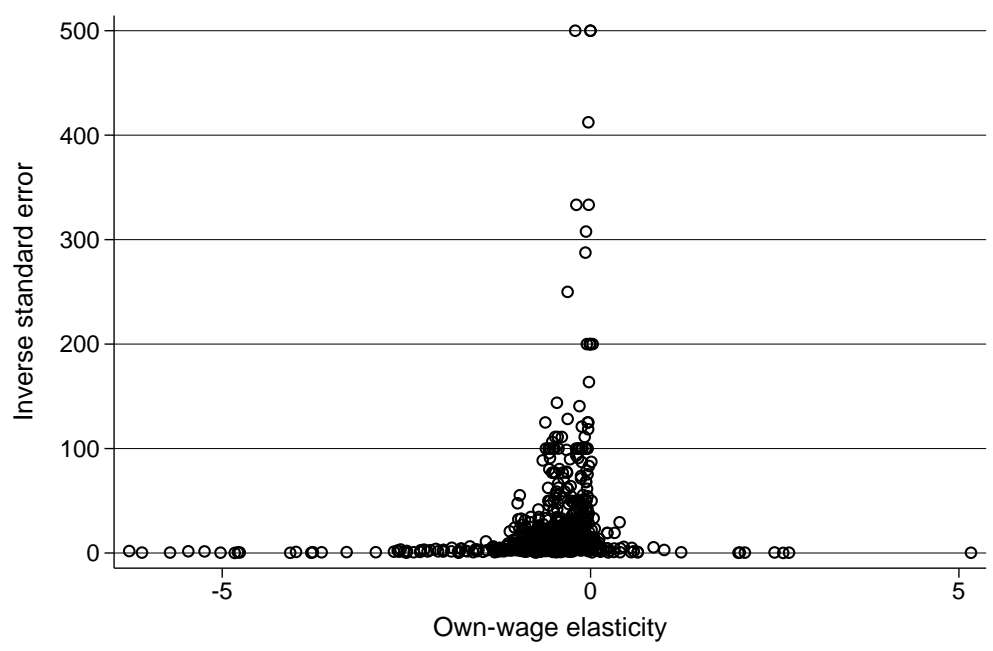

with the distribution being skewed to the left. In contrast, the graph shows only few non-negative estimates of the own-wage elasticity of labor demand at low precision. Figure 3 thus provides graphical evidence concerning the presence of publication selection bias. In the following, we thus explicitly account for publication selection bias within our meta-regression framework.

We evaluate the presence of publication selection bias within our most comprehensive meta-regression specification, given by column (5) of Table 3 . As the empirical results concerning the sources of heterogeneity remain unchanged, we limit our presentation to those variables indicating publication bias though. ${ }^{17}$

Column (1) of Table 3 shows that the standard error has a particularly strong

\footnotetext{
${ }^{17}$ The full regression results are provided in Table B.1 in Appendix B.
} 
Table 3: Testing for publication selection bias

\begin{tabular}{lccccc}
\hline Model & $(1)$ & $(2)$ & $(3)$ & $(4)$ & $(5)$ \\
\hline Constant & $-0.452^{* * *}$ & $-0.415^{* *}$ & $-0.436^{* * *}$ & $-0.488^{* * *}$ & $-0.466^{* * *}$ \\
& $(0.164)$ & $(0.161)$ & $(0.164)$ & $(0.176)$ & $(0.175)$ \\
Standard error & $-1.218^{* * *}$ & $-1.418^{* * *}$ & $-0.930^{* * *}$ & $-1.720^{* * *}$ & $-1.363^{* * *}$ \\
& $(0.322)$ & $(0.510)$ & $(0.298)$ & $(0.395)$ & $(0.343)$ \\
Normalized impact factor & & -0.198 & & & \\
& & $(0.146)$ & & & -1.132 \\
Std. error*Normalized impact factor & & 0.778 & & & $(0.789)$ \\
& & $(1.001)$ & & & $0.893^{*}$ \\
Std. error*Short-run elasticity & & & $-1.470^{*}$ & & $(0.518)$ \\
Std. error*Structural-form model & & & & & \\
& & & & & \\
& & & & & \\
No. of observations & & & & & \\
R-Squared & 924 & 924 & 924 & 924 & $0.566)$ \\
Adjusted R-Squared & 0.861 & 0.862 & 0.863 & 0.863 & 0.863 \\
\hline
\end{tabular}

Note: Standard errors (in parentheses) are clustered at the study level. Significance levels are $0.1(*), 0.05(* *)$ and $0.01(* * *)$.

and statistically significant effect on the own-wage elasticity of labor demand in our model. Thus, there is substantial evidence for publication selection bias. Estimates of the own-wage elasticity of labor demand are upwardly inflated. Given this clear evidence, we next analyze whether publication bias is more distinct in published papers and differs with the quality of the journal. We thus control for the impact factor of the respective journal within which the own-wage elasticity estimate was published and interact the standard error with the impact factor variable ${ }^{18}$ Column (2) shows the corresponding results. Evaluated at the mean level of the journals' impact factors, the parameter of the standard error is -1.180 and statistically significant at the $1 \%$ level. However, we find no statistically significant effect of the journal's impact factor on the extent of publication bias. Nonetheless, the coefficient on the interaction is large and positive, which suggests that publication bias is smaller in more influential journals. In detail, we find that the slope of the standard error variable decreases (increases) to $-1.396(-0.964)$ in case the normalized input factor decreases (increases) by one standard deviation from its mean.

Lastly, we evaluate whether publication bias might be affected by the theoretical or empirical specification. Precisely, we test whether publication bias is stronger for short-run than for intermediate- and long-run elasticities of labor demand and

\footnotetext{
${ }^{18}$ In detail, we used IDEAS/RePEc Simple Impact Factor as of October 23, 2013. The impact factor is normalized to a range between zero and one.
} 
is less pronounced in case the elasticity estimate is obtained from a structural-form model. For the former hypothesis, we reason that obtaining a non-negative or insignificant point estimate is more likely in case estimating a short-run rather than a long-run elasticity of labor demand. In turn, publication selection bias might be more pronounced for short-run elasticities. Likewise, we expect that publication selection bias is less distinct for those estimates that are based on structural-form models. The model is determined by theory and no adjustments of the functional form or the controls are feasible. The specification of reduced-form models might be easily adjusted in turn. The results given in columns (4) and (5) indeed confirm our hypotheses as publication bias is particularly stronger for short-run rather than intermediate- and long-run elasticities and less distinct in case the elasticities are obtained from a structural-form model. From column (6), we further infer that the latter effect remains statistically significant in case we include both interaction terms in one regression. Publication selection bias is particularly strong in case the elasticity is obtained from a reduced-form model.

\subsection{Sensitivity analysis}

Our previous regression results show that a considerable share of the heterogeneity in the estimated own-wage elasticity of labor demand can be explained by theoretical and empirical characteristics of the estimates, which are upwardly inflated due to publication selection bias though. In this section, we test the sensitivity of these results when (i) restricting the sample along various characteristics and (ii) using different estimators.

We restrict the sample along five dimensions, successively considering estimates from published studies, negative own-wage elasticities and statistically significant estimates only. Moreover, we discard elasticities based on aggregate country data and from studies published prior to 1993, respectively. Overall, our empirical findings are robust to restrictions in the sample, in terms of both heterogeneity and publication selection bias. Interestingly, when restricting the sample to statistically significant estimates, we find that panel data estimates of the own-wage elasticity of labor demand significantly exceed non-panel estimates in absolute terms. All 
corresponding regression results are provided in Table A.3 in the Appendix of this paper.

In terms of estimation, sensitivity is tested by means of running 'random effects'-meta ${ }^{19}$ and simple OLS regressions. Our empirical findings with respect to the sources of heterogeneity and the presence of publication selection bias are rather insensitive to different estimators. Evaluating differences in results, both 'random effects' meta-regression and simple OLS provide statistically and economically significant higher estimates of the own-wage elasticity of labor demand in case the wage rate is instrumented, even if we control for country-specific differences and the year of publication. In contrast, differences in the own-wage elasticity estimates that base on administrative rather than survey data sources turn statistically insignificant. Full regression results are reported in Table A.4 in the Appendix of this paper. The table also includes results based on the full sample of estimates, including those that did not report standard errors. The results are qualitatively and quantitatively very similar to our baseline estimates.

\section{Conclusion}

The own-wage elasticity of labor demand serves as a key figure in economic research and policy analysis, determining the effectiveness of policy reforms and the outcomes of many economic models. The importance of correctly assessing firms' labor demand responses is reflected by the large number of empirical studies devoted to the estimation of labor demand elasticities. Nonetheless, consensus on the genuine value of the own-wage elasticity of labor demand has not been achieved among labor economists and heterogeneity in the estimates of the own-wage labor demand elasticity is apparent.

In this paper, we explicitly evaluate potential sources of heterogeneity affecting estimates of the elasticity of labor demand by means of a meta-regression analysis

\footnotetext{
${ }^{19}$ Here, an additional between-study variance term is estimated in a first step (Feld and Heckemeyer, 2011) to cover differences in the estimates beyond pure sampling error and those captured by the control variables. Despite being a standard tool in meta-regression analysis, Stanley and Doucouliagos (2013) show that WLS outperforms the 'random effects' meta-regression estimator.
} 
of the relevant literature. Building on 942 estimates of the own-wage elasticity of labor demand from 105 different micro-level studies, we explain more than $80 \%$ of the variation in the elasticity. We find heterogeneity in the estimates in accordance with theory, given that labor demand is less elastic in the short- than in the intermediateand long-run. In terms of the empirical set-up, we find that the model specification as well as the treatment of the wage variable affect the elasticity estimate, albeit with the effects vanishing when controlling for the study's year of publication and the country of interest. Moreover, our results show that the dataset used, the type of worker considered or industry and country evaluated affect the absolute value of the elasticity.

Besides explaining the variation in the estimates of the own-wage elasticity, we further explicitly test for publication selection bias in the empirical literature on labor demand. We find strong empirical evidence for substantial publication bias, estimates of the own-wage elasticity of labor demand being upwardly inflated. Here, publication bias is found to be particularly strong for estimates of the short-run elasticity of labor demand and low for estimates based on structural-form models.

Overall, our results suggest that there is not one unique value for the own-wage elasticity of labor demand; rather, heterogeneity matters with respect to several dimensions. Our preferred estimate in terms of specification - the long-run, constantoutput elasticity obtained from a structural-form model using administrative panel data at the firm level for the latest mean year of observation, with mean characteristics on all other variables and corrected for publication selection bias - is -0.246 , bracketed by the interval [-0.072;-0.446]. Compared to this interval, we note that (i) many estimates of the own-wage elasticity of labor demand given in the literature are upwardly inflated (with a mean value larger than -0.5 in absolute terms) and (ii) our preferred estimate is close to the best guess provided by Hamermesh (1993), albeit with our confidence interval for values of the elasticity being smaller. 


\section{References}

Abraham, F. and J. Konings (1999). Does the Opening of Central and Eastern Europe Threaten Employment in the West? The World Economy 22(4), 585601.

Addison, J. and P. Texeira (2001). Employment Adjustment in a 'Sclerotic' Labor Market: Comparing Portugal with Germany, Spain and the United Kingdom. Journal of Economics and Statistics (Jahrbuecher fuer Nationaloekonomie und Statistik) 221(4), 353-370.

Addison, J. and P. Texeira (2005). Employment adjustment in two countries with poor reputations: Analysis of aggregate, firm, and flow data for Portugal and Germany. International Economics and Economic Policy 1, 329-348.

Aguilar, G. and S. Rendon (2008). Matching bias in labor demand estimation. Economics Letters $100(2), 297-299$.

Aguilar, G. and S. Rendon (2010). Employment And Deadweight Loss Effects Of Observed Nonwage Labor Costs. Economic Inquiry 48(3), 793-809.

Allen, C. and G. Urga (1999). Interrelated Factor Demands from Dynamic Cost Functions: An Application to the Non-energy Business Sector of the UK Economy. Economica 66(263), 403-413.

Allen, S. G. (1986). Union Work Rules and Efficiency in the Building Trades. Journal of Labor Economics 4 (2), 212-242.

Amiti, M. and S.-J. Wei (2005). Fear of Service Outsourcing: Is it justified? Economic Policy 20(42), 308-347.

Amiti, M. and S.-J. Wei (2006). Service Offshoring, Productivity and Employment: Evidence from the US. CEPR Discussion Papers 5475.

Arellano, M. and S. Bond (1991). Some Tests of Specification for Panel Data: Monte Carlo Evidence and an Application to Employment Equations. The Review of Economic Studies 58(2), 227-297.

Arnone, L., C. Dupont, B. Mahy, and S. Spataro (2005). Human resource management and labour demand dynamics in Belgium. International Journal of Manpower 26(7/8), 724-743.

Atkinson, S. E. and R. Halvorsen (1984). Parametric Efficiency Tests, Economies of Scale, Input Demand in U.S. Electric Power Generation. International Economic Review 25(3), 647-662.

Ayala, S. (2012). Payroll Taxes and Labour Demand: Evidence from Colombian Manufacturing Industry. Discussion Paper.

Barba Navaretti, G., A. Turrini, and D. Checchi (2003). Adjusting Labor Demand: Multinational Versus National Firms: A Cross-European Analysis. Journal of the European Economic Association 1(2-3), 708-719. 
Basu, S., S. Estrin, and J. Svejnar (2005). Employment Determination in Enterprises under Communism and in Transition: Evidence from Central Europe. Industrial and Labor Relations Review 58(3), 353-369.

Becker, S. O., K. Ekholm, R. Jäckle, and M.-A. Muendler (2005). Location Choce and Employment Decisions: A Comparison of German and Swedish Multinationals. Review of World Economics (Weltwirtschaftliches Archiv) 141(4), 693-731.

Bellmann, L., S. Bender, and T. Schank (1999). Flexibilität der Qualifikationstruktur aus betrieblicher Sicht: Substitutionalität oder Komplementarität. Jahrbücher für Nationalökonomie und Statistik 219(1+2), 109-126.

Bellmann, L., M. Caliendo, R. Hujer, and D. Radic (2002). Beschäftigungswirkungen technisch-organisatorischen Wandels: Eine mikroökonometrische Analyse mit dem Linked IAB Panel. Mitteilungen aus der Arbeitsmarkt- und Berufsforschung 35(4), 506-522.

Bellmann, L. and A. Pahnke (2006). Auswirkungen organisatorischen Wandels auf die betriebliche Arbeitsnachfrage. Zeitschrift für Arbeitsmarktforschung 39(2), 201-233.

Bellmann, L. and T. Schank (2000). Innovations, Wages and Demand for Heterogeneous Labour: New Evidence from a Matched Employer-Employee Data-Set. IZA Discussion Paper Series 112.

Bernal, R. and M. Cardenas (2004). Determinants of Labor Demand in Colombia: 1976-1996. In J. J. Heckman and C. Pagés (Eds.), Law and Employment: Lessons from Latin American and the Caribbean.

Blechinger, D., A. Kleinknecht, G. Licht, and F. Pfeiffer (1998). The impact of innovation on employment in Europe: An analysis using CIS data. $Z E W$ Dokumentation 98-02.

Blechinger, D. and F. Pfeiffer (1999). Qualifikation, Beschäftgigung und technischer Fortschritt. Jahrbücher für Nationalökonomie und Statistik 218, 128-146.

Blien, U., K. Kirchhof, and O. Ludwig (2006). Agglomeration Effects on Labor Demand. Discussion Paper.

Boeters, S. and L. Savard (2013). The Labor Market in Computable General Equilibrium Models. In P. W. Dixon and D. W. Jorgenson (Eds.), Handbook of Computable General Equilibrium Modeling SET, Volume 1, pp. 1645-1718.

Bohachova, O., B. Brookmann, and C. M. Buch (2011). Labor Demand During the Crisis: What Happened in Germany? IZA Discussion Paper Series 6074.

Braconier, H. and K. Ekholm (2000). Swedish Multinationals and Competition form High- and Low-Wage Locations. Review of International Economics 8(3), 448-461.

Brixy, U. and M. Fuchs (2010). How important are plant and regional characteristics for labor demand? Plant-level evidence from Germany. Discussion Paper. 
Bruno, G. S. F. and A. M. Falzoni (2005). Estimating a dynamic labour demand equation using small, unbalanced panels: An application to Italian manufacturing sectors. Discussion Paper.

Bruno, G. S. F., A. M. Falzoni, and R. Helg (2003). Measuring the effect of globalization on labour demand elasticity: An empirical application to OECD countries. Discussion Paper.

Buch, C. M. and A. Lipponer (2010). Volatile Multinationals? Evidence from the labor demand of German firms? Labour Economics 17(2), 345-353.

Cahuc, P. and B. Dormont (1997). Profit-sharing: Does it increase productivity and employment? A theoretical model and empirical evidence on French micro-data. Labour Economics 4 (3), 293-319.

Card, D., J. Kluve, and A. Weber (2010). Active Labour Market Evaluations: A Meta-Analysis. The Economic Journal 120, F452-F477.

Card, D. and A. B. Krueger (1995). Time-Series Minimum Wage Studies: A MetaAnalysis. American Economic Review Papers $\&$ Proceedings 85(2), 238-243.

Cassoni, A., S. G. Allen, and G. J. Labadie (2004). Unions and Employment in Uruguay. In J. J. Heckman and C. Pages (Eds.), Law and Employment: Lessons from Latin America and the Carribean. University of Chicago Press.

Crino, R. (2007). Skill-Biased Effects of Service Offshoring in Western Europe. CESPRI Discussion Paper.

Crino, R. (2012). Service Offshoring and the Skill Composition of Labour Demand. Oxford Bulletin of Economics and Statistics 74(1), 20-57.

DeLong, J. B. and K. Lang (1992). Are All Economic Hypothesis False? Journal of Political Economy 100(6), 1257-1272.

Denny, M., M. Fuss, C. Everson, and L. Waverman (1981). Estimating the Effects of Diffusion of Technological Innovations and Telecommunications: The Production Structure of Bell Canada. The Canadian Journal of Economics 14 (1), 24-43.

Diewert, W. E. and T. Wales (1987). Flexible Functional Forms and Global Curvature Conditions. Econometrica 55(1), 43-68.

Draper, N. and T. Manders (1997). Structural Change in the Demand for Labor. De Economist 145, 521-546.

Dunne, T. and M. J. Roberts (1993). The Long-Run Demand For Labor: Estimates From Census Establishment Data. Discussion Paper.

Ekholm, K. and K. Hakkala (2006). The Effect of Offshoring On Labour Demand: Evidence from Sweden. CEPR Discussion Papers 5648.

Fajnzylber, P. and W. F. Maloney (2005). Labor demand and trade reform in Latin America. Journal of International Economics 66(2), 423-446. 
Falk, M. (2001). Organizational Change, New Information and Communication Technologies and the Demand for Labor in Service. Discussion Paper.

Falk, M. and B. Koebel (1997). The Demand of Heterogeneous Labour in Germany. Discussion Paper 28.

Falk, M. and B. Koebel (1999). Curvature Conditions and substitution pattern among capital, energy, material and heterogeneous labor. ZEW Discussion Papers 99-06.

Falk, M. and B. Koebel (2001). A dynamic heterogeneous labour demand model for German manufacturing. Applied Economics 33(3), 339-348.

Falk, M. and B. Koebel (2002). Outsourcing, Imports and Labour Demand. Scandinavian Journal of Economics 104(4), 567-586.

Falk, M. and B. Koebel (2004). The impact of office machinery, and computer capital on the demand for heterogeneous labour. Labour Economics 11(1), 99-117.

Falk, M. and Y. Wolfmayr (2005). The Impact Of International Outsourcing On Employment: Empirical Evidence From EU Countries. Discussion Paper.

Feld, L. P. and J. H. Heckemeyer (2011). FDI and Taxation: A Meta-Study. Journal of Economic Surveys 25(2), 233-272.

Field, B. C. and C. Grebenstein (1980). Capital-Energy Substitution in U.S. Manufacturing. The Review of Economics and Statistics 62(2), 207-212.

Fitzroy, F. and M. Funke (1994). Real Wages, Net Investment and Employment: New Evidence from West German Sectoral Data. Review of World Economics (Weltwirtschaftliches Archiv) 130(2), 258-272.

FitzRoy, F. and M. Funke (1998). Skills, Wages and Employment in East and West Germany. Regional Studies 32(5), 459-467.

Freier, R. and V. Steiner (2010). 'Marginal Employment' and the demand for heterogeneous labor - elasticity estimates from a multi-factor labour demand model for Germany. Applied Economics Letters 17(12), 1177-1182.

Fu, X. and V. N. Balasubramanyam (2005). Exports, Foreign Direct Investment and Employment: The Case of China. The World Economy 28(4), 607-625.

Fuchs, V. R., A. B. Krueger, and J. M. Poterba (1998, September). Economists' Views about Parameters, Values, and Policies: Survey Results in Labor and Public Economics. Journal of Economic Literature 36, 1387-1425.

Funke, M., W. Maurer, and H. Strulik (1999). Capital Structure and Labour Demand: Investigations Using German Micro Data. Oxford Bulletin of Economics and Statistics 61(2), 199-215.

Godart, O. N., H. Görg, and D. Greenaway (2009). Headquarter services, skill intensity and labour demand elasticities in multinational firms. Discussion Paper 1575. 
Grant, J. H. and D. H. Hamermesh (1981). Labor Market Competition Among Youth, White Women And Others. The Review of Economics and Statistics 63(3), $354-360$.

Greenaway, D., R. C. Hine, and P. Wright (1999). An empirical assessment of the impact of trade on employment in the United Kingdom. European Journal of Political Economy 15(3), 485-500.

Görg, H. and A. Hanley (2005). Labour demand effects of international outsourcing: Evidence from plant-level data. International Review of Economics and Finance 14(3), 365-376.

Görg, H., M. Henry, E. Strobl, and F. Walsh (2009). Multinational companies, backward linkages, and labour demand elasticities. Canadian Journal of Economics 42(1), 332-348.

Griffin, P. (1992). The Impact of Affirmative Action on Labor Demand: A Test of Some Implications of the Le Chatelier Principle. The Review of Economics and Statistics 74(2), 251-260.

Griffin, P. (1996). Input Demand Elasticities for Heterogeneous Labor: Firm-Level Estimates and an Investigation into the Effects of Aggregation. Southern Economic Journal 62(4), 889-901.

Hakkala, K., F. Heyman, and F. Sjöholm (2010). Multinationals, skills, and wage elasticities. Review of World Economics (Weltwirtschaftliches Archiv) 146(2), $263-280$.

Halvorsen, R. and T. R. Smith (1986). Substitution Possibilities for Unpriced Natural Resources: Restricted Cost Functions for the Canadian Metal Mining Industry. The Review of Economics and Statistics 68(3), 398-405.

Hamermesh, D. H. (1993). Labor Demand. Princeton University Press.

Haouas, I. and M. Yagoubi (2007). Trade Liberalization and Labor-Demand Elasticities: Empirical Evidence from Tunisia. Applied Economics Letters 15(4), 277-286.

Harrison, A. E. and M. S. McMillan (2006). Outsourcing Jobs? Multinationals And US Employment. NBER Working Paper Series 12372.

Hasan, R., D. Mitra, and K. V. Ramaswamy (2007). Trade Reforms, Labor Regulations, And Labor-Demand Elasticities: Empirical Evidence From India. The Review of Economics and Statistics 89(3), 466-481.

Hatzius, J. (1998). Domestic Jobs and Foreign Wages. Scandinavian Journal of Economics $100(4), 733-746$.

Hijzen, A., H. Görg, and R. C. Hine (2005). International Outsourcing And The Skill Structure Of Labour Demand In The United Kingdom. The Economic Journal 115(506), 860-878. 
Hijzen, A. and P. Swaim (2010). Offshoring, labour market institutions and the elasticity of labour demand. European Economic Review 54(8), 1016-1034.

Hine, R. C. and P. Wright (1998). Trade with Low Wage Economies, Employment and Productivity in UK Manufacturing. Economic Journal 108(450), 1500-1510.

Jacobi, L. and S. Schaffner (2008). Does Marginal Employment Substitute Regular Employment? A Heterogeneous Dynamic Labor Demand Approach for Germany. Ruhr Economic Papers 56.

Jacquet, L., E. Lehmann, and B. V. der Linden (2012). Optimal Redistributive Taxation with both Labor Supply and Labor Demand Responses. CESifo Working Paper 3779 .

Kim, Y. H. (1988). Analyzing the Indirect Production Function for U.S. Manufacturing. Southern Economic Journal 55(2), 494-504.

Kölling, A. (2012). Firm Size And Employment Dynamics: Estimations of Labor Demand Elasticities Using a Fractional Panel Probit Model. Labour 26(2), 174207.

Koebel, B. (1998). Tests of Representative Firm Models: Results for German Manufacturing Industries. Journal of Productivity Analysis 10(3), 251-270.

Koebel, B. (2002). Can Aggregation Across Goods Be Achieved By Neglecting The Problem? Property Inheritance And Aggregation Bias. International Economic Review.

Koebel, B. (2006). Exports and Labor Demand: Searching for Structure in MultiOutput Multi-Skill Technologies. Journal of Business and Economics Statistics $24(1), 91-103$.

Koebel, B., M. Falk, and F. Laisney (2003). Imposing and Testing Curvature Conditions on a Box-Cox Function. Journal of Business and Economics Statistics 21(2), $319-335$.

Kokkelenberg, E. C. and J. P. Choi (1986). Factor demands, adjustment costs and regulation. Applied Economics 18, 631-643.

Konings, J. and A. P. Murphy (2004). Do Multinational Enterprises Relocate Employment to Low Wage Regions? Evidence from European Multinationals. Discussion Paper.

Konings, J. and H. Vandenbussche (1995). The Effect of Foreign Competition on UK Employment and Wages: Evidence from Firm-Level Plant Data. Review of World Economics (Weltwirtschaftliches Archiv) 131(4), 655-672.

Krishna, P., D. Mitra, and S. Chinoy (2001). Trade liberalization and labour demand elasticities: evidence from Turkey. Journal of International Economics 55(2), 391-409. 
Lachenmaier, S. and H. Rottmann (2007). Employment Effects of Innovation at the Firm Level. Journal of Economics and Statistics (Jahrbuecher fuer Nationaloekonomie und Statistik) 227(3), 254-272.

Lindquist, K.-G. (1995). The Existence of Factor Substitution in the Primary Aluminium Industry: A Multivariate Error-Correction Approach Using Norwegian Panel Data. Empirical Economics 20(3), 361-383.

Mairesse, J. and B. Dormont (1985). Labor and Investment Demand At The Firm Level - A Comparison Of French, German and U.S. Manufacturing, 1970-79. European Economic Review 28(1-2), 201-231.

Micevska, M. (2008). The Labour Market in Macedonia: A Labour Demand Analysis. Labour 22(2), 345-368.

Milner, C. and P. Wright (1998). Modelling Labour Market Adjustment To Trade Liberalisation In An Industrialising Economy. The Economic Journal 108(March), 509-528.

Mitra, D. and J. Shin (2011). Import protection, exports and labor-demand elasticities: Evidence from Korea. International Review of Economics and Finance 23(C), 91-109.

Molnar, M. N. and D. Taglioni (2007). The Internationalisation of Production, International Outsourcing and Employment in the OECD. OECD Economics Department Working Papers 561.

Mondino, G. and S. Montoya (2004). The Effects of Labor Market Regulations on Employment Decisions by Firms. Empirical Evidence for Argentina. In Law and Employment: Lessons from Latin America and the Carribean. University of Chicago Press.

Morrison, C. J. (1988). Quasi-fixed Inputs in U.S. and Japanese Manufacturing: a Generalized Leontief Restricted Cost Function Approach. The Review of Economics and Statistics 70(2), 275-287.

Muendler, M.-A. and S. O. Becker (2010). Margins of Multinational Labor Substitution. American Economic Review 100(December), 1999-2030.

Nissim, J. (1984). The Price Responsiveness of Demand for Labour by Skill: Britsh Mechanical Engineering: 1963-1978. The Economic Journal 94(376), 812-825.

Ogawa, K. (2003). Financial Distress And Employment: The Japanese Case in the 90s. NBER Working Paper Series 9646.

Onaran, O. (2008). Jobless Growth in the Central and East European Countries. Eastern European Economics 46(4), 90-115.

Pencavel, J. and B. Holmlund (1988). The Determination of Wages, Employment, and Work Hours in an Economy with Centralised Wage-Setting: Sweden, 19501983. The Economic Journal 98(393), 1105-1126. 
Rauch, J. E. and V. Trindade (2003). Information, International Substitutability, and Globalization. American Economic Review 93(3), 775-791.

Revenga, A. (1997). Employment and Wage Effects of Trade Liberalization: The Case of Mexican Manufacturing. Journal of Labor Economics 15(S3), S20-S43.

Riedel, N. (2011). Taxing Multinationals under Union Wage Bargaining. International Tax and Public Finance 18(4), 399-421.

Roberts, M. J. and E. Skoufias (1998). The Long-Run Demand For Skilled And Unskilled Labor In Colombian Manufacturing Plants. The Review of Economics and Statistics 79(2), 330-334.

Rodrik, D. (1997). Has Globalization Gone Too Far? Institute For International Economics.

Rottmann, H. and M. Ruschinski (1998). The Labour Demand and the Innovation Behaviour of Firms. Journal of Economics and Statistics (Jahrbuecher fuer Nationaloekonomie und Statistik) 217(6), 741-752.

Saavedra, J. and M. Torero (2004). Labor Market Reforms and Their Impact over Formal Labor Demand and Job Market Turnover. The Case of Peru. In Law and Employment: Lessons from Latin America and the Carribean. University of Chicago Press.

Senses, M. Z. (2010). The effects of offshoring on the elasticity of labor demand. Journal of International Economics 81(1), 89-98.

Slaughter, M. J. (2001). International trade and labor-demand elasticities. Journal of International Economics 54(1), 27-56.

Stanley, T. and C. Doucouliagos (2013). Neither fixed or random: Weighted Least Squares Meta-Analysis. Working Paper.

Sutton, A., K. R. Abrams, D. R. Jones, T. R. Sheldon, and F. Song (2000). Methods for Meta-Analysis in Medical Research. Wiley.

Symmons, J. and R. Layard (1984). Neoclassical Demand for Labour Functions For Six Major Economies. The Economic Journal 94(376), 788-799.

Terrell, D. (1996). Incorporating Monotonicity And Concavity Conditions In Flexible Functional Forms. Journal of Applied Econometrics 11, 179-194.

VanReenen, J. (1997). Employment and Technological Innovation: Evidence from U.K. Manufacturing Firms. Journal of Labor Economics 15(2), 255-284.

Wadhwani, S. B. (1987). The Effects of Inflation and Real Wages on Employment. Economica 54(213), 21-40.

Wadhwani, S. B. and M. Wall (1990). The Effects of Profit-Sharing on Employment, Wages, Stock Returns and Productivity: Evidence from UK Micro-Data. The Economic Journal 100(399), 1-17. 
Wolfson, P. (1993). Compositional Change, Aggregation, And Dynamic Factor Demand - Estimates On A Panel Of Manufacturing Firms. Journal of Applied Econometrics 8, 129-148. 


\section{A Appendix}

Table A.1: Distribution of labor demand elasticities by publication data and country

\begin{tabular}{|c|c|c|c|c|c|}
\hline & Estimates & Share & & Estimates & Share \\
\hline \multicolumn{6}{|l|}{ Country } \\
\hline Aggregate Data & 139 & 15.04 & Macedonia & 4 & 0.43 \\
\hline Aggregate European Data & 22 & 2.38 & Mauritius & 2 & 0.22 \\
\hline Argentina & 4 & 0.43 & Mexico & 7 & 0.76 \\
\hline Belgium & 6 & 0.65 & Netherlands & 5 & 0.54 \\
\hline Bulgaria & 2 & 0.22 & Norway & 3 & 0.32 \\
\hline Canada & 4 & 0.43 & Peru & 14 & 1.52 \\
\hline Chile & 2 & 0.22 & Poland & 7 & 0.76 \\
\hline China & 1 & 0.11 & Portugal & 3 & 0.32 \\
\hline Colombia & 30 & 3.25 & Romania & 1 & 0.11 \\
\hline Czech Republic & 9 & 0.97 & Slovak Republic & 6 & 0.65 \\
\hline Denmark & 1 & 0.11 & Slovenia & 1 & 0.11 \\
\hline Finland & 1 & 0.11 & South Korea & 4 & 0.43 \\
\hline France & 12 & 1.30 & Spain & 6 & 0.65 \\
\hline Germany & 253 & 27.38 & Sweden & 30 & 3.25 \\
\hline Hungary & 9 & 0.97 & Tunisia & 24 & 2.60 \\
\hline India & 4 & 0.43 & Turkey & 53 & 5.74 \\
\hline Ireland & 8 & 0.87 & United Kingdom & 61 & 6.60 \\
\hline Italy & 11 & 1.19 & United States & 152 & 16.45 \\
\hline Japan & 16 & 1.73 & Uruguay & 5 & 0.54 \\
\hline Lithuania & 2 & 0.22 & & & \\
\hline \multicolumn{6}{|l|}{ Year of publication } \\
\hline 1980 & 10 & 1.08 & 1998 & 59 & 6.39 \\
\hline 1981 & 5 & 0.54 & 1999 & 17 & 1.84 \\
\hline 1984 & 18 & 1.95 & 2000 & 7 & 0.76 \\
\hline 1985 & 2 & 0.22 & 2001 & 79 & 8.55 \\
\hline 1986 & 38 & 4.11 & 2002 & 13 & 1.41 \\
\hline 1987 & 1 & 0.11 & 2003 & 65 & 7.03 \\
\hline 1988 & 12 & 1.30 & 2004 & 33 & 3.57 \\
\hline 1990 & 1 & 0.11 & 2005 & 75 & 8.12 \\
\hline 1991 & 8 & 0.87 & 2006 & 46 & 4.98 \\
\hline 1992 & 16 & 1.73 & 2007 & 53 & 5.74 \\
\hline 1993 & 19 & 2.06 & 2008 & 81 & 8.77 \\
\hline 1994 & 2 & 0.22 & 2009 & 9 & 0.97 \\
\hline 1995 & 6 & 0.65 & 2010 & 181 & 19.59 \\
\hline 1996 & 19 & 2.06 & 2011 & 7 & 0.76 \\
\hline 1997 & 29 & 3.14 & 2012 & 13 & 1.41 \\
\hline
\end{tabular}

Note: Total number of elasticities obtained is 942. In case of Discussion Papers, the year of publication refers to the latest available version of the respective study. 
Table A.2: Distribution of labor demand elasticities by sector/industry

\begin{tabular}{lcc}
\hline & Estimates & Share (in \%) \\
\hline All sectors & 323 & 34.96 \\
Mining (B) & 3 & 0.32 \\
Manufacturing (C) & 392 & 42.42 \\
Manufacture of food,beverages, tobacco (10-12) & 6 & 0.65 \\
Manufacture of textiles, apparel,leather (13-15) & 6 & 0.65 \\
Manufacture of wood \& wood products (16) & 3 & 0.32 \\
Manufacture of paper \& paper products (17) & 7 & 0.76 \\
Printing (18) & 1 & 0.11 \\
Manufacture of coke \& petroleum (19) & 2 & 0.22 \\
Manufacture of chemicals \& chemical products (20) & 16 & 1.73 \\
Manufacture of rubber \& plastic products (22) & 2 & 0.22 \\
Manufacture of non-metallic mineral products (23) & 11 & 1.19 \\
Manufacture of basic metals (24) & 8 & 0.87 \\
Manufacture of metal products (25) & 6 & 0.65 \\
Manufacture of electrical equipment (27) & 5 & 0.54 \\
Manufacture of machinery (28) & 10 & 1.08 \\
Manufacture of transport equipment (30) & 8 & 0.87 \\
Other manufacturing (32) & 15 & 1.62 \\
Electricity, gas and water supply (D-E) & 5 & 0.54 \\
Construction (F) & 52 & 5.63 \\
Wholesale (G) & 3 & 0.32 \\
Service (I-S) & 36 & 3.90 \\
Information and communication (J) & 1 & 0.11 \\
Financial \& insurance services (K) & 3 & 0.32 \\
\hline Note: Total nut & & \\
\hline
\end{tabular}

Note: Total number of elasticities obtained is 942. Industrial classification according to ISIC Rev.4 of the United Nations Statistics Division. Due to changes in the ISIC classification over time, industries $10-12,13-15, D-E$ had to be pooled. 
Table A.3: Sensitivity checks: Meta-regression analysis on reduced samples

\begin{tabular}{|c|c|c|c|c|c|}
\hline Model & $(1)$ & $(2)$ & (3) & $(4)$ & $(5)$ \\
\hline Constant & $\begin{array}{l}-0.196 \\
(0.161)\end{array}$ & $\begin{array}{l}-0.077 \\
(0.180)\end{array}$ & $\begin{array}{c}0.040 \\
(0.163)\end{array}$ & $\begin{array}{l}-0.045 \\
(0.166)\end{array}$ & $\begin{array}{l}-0.071 \\
(0.167)\end{array}$ \\
\hline \multicolumn{6}{|l|}{ Specification } \\
\hline \multicolumn{6}{|l|}{ Time period (omitted: Short-run) } \\
\hline Intermediate-run & $\begin{array}{c}-0.098^{*} \\
(0.053)\end{array}$ & $\begin{array}{l}-0.090^{*} \\
(0.046)\end{array}$ & $\begin{array}{c}-0.150^{* * *} \\
(0.037)\end{array}$ & $\begin{array}{l}-0.095^{*} \\
(0.051)\end{array}$ & $\begin{array}{l}-0.054^{*} \\
(0.028)\end{array}$ \\
\hline Long-run & $\begin{array}{c}-0.095^{* * *} \\
(0.022)\end{array}$ & $\begin{array}{c}-0.113^{* * *} \\
(0.041)\end{array}$ & $\begin{array}{c}-0.157^{* *} \\
(0.065)\end{array}$ & $\begin{array}{l}-0.081^{*} \\
(0.042)\end{array}$ & $\begin{array}{r}-0.138^{* * *} \\
(0.035)\end{array}$ \\
\hline \multicolumn{6}{|c|}{ Labor demand model (omitted: Conditional/Reduced-form) } \\
\hline Conditional/Structural-form & $\begin{array}{c}0.122 \\
(0.083)\end{array}$ & $\begin{array}{l}-0.003 \\
(0.068)\end{array}$ & $\begin{array}{l}-0.007 \\
(0.073)\end{array}$ & $\begin{array}{l}-0.014 \\
(0.070)\end{array}$ & $\begin{array}{l}-0.029 \\
(0.066)\end{array}$ \\
\hline Unconditional/Reduced-form & $\begin{array}{c}0.087 \\
(0.056)\end{array}$ & $\begin{array}{l}-0.015 \\
(0.052)\end{array}$ & $\begin{array}{c}-0.051^{* *} \\
(0.026)\end{array}$ & $\begin{array}{c}0.026 \\
(0.064)\end{array}$ & $\begin{array}{l}-0.000 \\
(0.053)\end{array}$ \\
\hline Unconditional/Structural-form & $\begin{array}{c}0.026 \\
(0.105)\end{array}$ & $\begin{array}{l}-0.015 \\
(0.099)\end{array}$ & $\begin{array}{l}-0.034 \\
(0.106)\end{array}$ & $\begin{array}{l}-0.036 \\
(0.103)\end{array}$ & \\
\hline Instrumenting wages & $\begin{array}{c}0.037 \\
(0.043)\end{array}$ & $\begin{array}{c}0.033 \\
(0.035)\end{array}$ & $\begin{array}{c}0.028 \\
(0.036)\end{array}$ & $\begin{array}{c}0.040 \\
(0.038)\end{array}$ & $\begin{array}{c}0.041 \\
(0.038)\end{array}$ \\
\hline \multicolumn{6}{|l|}{ Dataset } \\
\hline \multicolumn{6}{|c|}{ Panel data specification (omitted: No panel data) } \\
\hline Panel data/No unit-fixed effects & $\begin{array}{c}-0.191^{* *} \\
(0.087)\end{array}$ & $\begin{array}{l}-0.133 \\
(0.138)\end{array}$ & $\begin{array}{l}-0.217^{*} \\
(0.123)\end{array}$ & $\begin{array}{l}-0.168 \\
(0.108)\end{array}$ & $\begin{array}{l}-0.144 \\
(0.123)\end{array}$ \\
\hline Panel data/Unit-fixed effects & $\begin{array}{c}-0.164^{*} \\
(0.084)\end{array}$ & $\begin{array}{l}-0.111 \\
(0.137)\end{array}$ & $\begin{array}{l}-0.192 \\
(0.121)\end{array}$ & $\begin{array}{l}-0.144 \\
(0.109)\end{array}$ & $\begin{array}{l}-0.149 \\
(0.121)\end{array}$ \\
\hline Administrative data & $\begin{array}{c}0.014 \\
(0.130)\end{array}$ & $\begin{array}{c}0.221^{* *} \\
(0.111)\end{array}$ & $\begin{array}{c}0.239^{* *} \\
(0.109)\end{array}$ & $\begin{array}{c}0.131 \\
(0.080)\end{array}$ & $\begin{array}{c}0.229^{* * *} \\
(0.081)\end{array}$ \\
\hline Industry level data & $\begin{array}{l}-0.060 \\
(0.057)\end{array}$ & $\begin{array}{l}-0.032 \\
(0.073)\end{array}$ & $\begin{array}{l}-0.074 \\
(0.059)\end{array}$ & $\begin{array}{l}-0.043 \\
(0.060)\end{array}$ & $\begin{array}{l}-0.045 \\
(0.052)\end{array}$ \\
\hline \multicolumn{6}{|l|}{ Workforce characteristics } \\
\hline \multicolumn{6}{|l|}{ Skill level (omitted: All workers) } \\
\hline High-skilled workers & $\begin{array}{l}0.135^{*} \\
(0.076)\end{array}$ & $\begin{array}{c}0.037 \\
(0.072)\end{array}$ & $\begin{array}{l}-0.022 \\
(0.108)\end{array}$ & $\begin{array}{l}-0.047 \\
(0.056)\end{array}$ & $\begin{array}{c}0.036 \\
(0.087)\end{array}$ \\
\hline Unskilled workers & $\begin{array}{c}-0.197^{* * *} \\
(0.038)\end{array}$ & $\begin{array}{c}-0.221^{* * *} \\
(0.035)\end{array}$ & $\begin{array}{c}-0.214^{* * *} \\
(0.036)\end{array}$ & $\begin{array}{c}-0.161^{* * *} \\
(0.044)\end{array}$ & $\begin{array}{c}-0.194^{* * *} \\
(0.038)\end{array}$ \\
\hline Demand for female workers & $\begin{array}{c}-0.156^{* * *} \\
(0.024)\end{array}$ & $\begin{array}{c}-0.148^{* * *} \\
(0.020)\end{array}$ & $\begin{array}{c}-0.140^{* * *} \\
(0.022)\end{array}$ & $\begin{array}{c}-0.152^{* * *} \\
(0.027)\end{array}$ & $\begin{array}{l}-0.219 \\
(0.311)\end{array}$ \\
\hline Atypical employment & $\begin{array}{l}-0.228 \\
(0.189)\end{array}$ & $\begin{array}{c}-0.507^{* * *} \\
(0.076)\end{array}$ & $\begin{array}{c}-0.550^{* * *} \\
(0.059)\end{array}$ & $\begin{array}{c}-0.537^{* * *} \\
(0.067)\end{array}$ & $\begin{array}{c}-0.546^{* * *} \\
(0.061)\end{array}$ \\
\hline \multicolumn{6}{|l|}{ Publication selection bias } \\
\hline Standard error & $\begin{array}{c}-1.569^{* * *} \\
(0.394)\end{array}$ & $\begin{array}{c}-1.514^{* * *} \\
(0.354)\end{array}$ & $\begin{array}{c}-2.194^{* * *} \\
(0.507)\end{array}$ & $\begin{array}{c}-1.338^{* * *} \\
(0.359)\end{array}$ & $\begin{array}{c}-1.318^{* * *} \\
(0.366)\end{array}$ \\
\hline No. of observations & 708 & 866 & 651 & 763 & 794 \\
\hline Adjusted R-Squared & 0.856 & 0.859 & 0.838 & 0.865 & 0.818 \\
\hline
\end{tabular}

Note: Standard errors (in parentheses) are clustered at the study level. Significance levels are $0.1(*), 0.05\left({ }^{* *}\right)$, and $0.01{ }^{(* * *)}$. 
Table A.4: Sensitivity Checks: Meta-regression analysis using different estimators

\begin{tabular}{|c|c|c|c|c|c|}
\hline Model & RE Meta & RE Meta & RE Meta & OLS & OLS \\
\hline Constant & $\begin{array}{c}-0.328^{* * *} \\
(0.057)\end{array}$ & $\begin{array}{c}0.267 \\
(0.228)\end{array}$ & $\begin{array}{c}0.217 \\
(0.219)\end{array}$ & $\begin{array}{l}-0.022 \\
(0.187)\end{array}$ & $\begin{array}{c}0.193 \\
(0.144)\end{array}$ \\
\hline \multicolumn{6}{|l|}{ Specification } \\
\hline \multicolumn{6}{|l|}{ Time period (omitted: Short-run) } \\
\hline Intermediate-run & $\begin{array}{c}-0.110^{* * *} \\
(0.032)\end{array}$ & $\begin{array}{c}-0.157^{* * *} \\
(0.040)\end{array}$ & $\begin{array}{c}-0.110^{* * *} \\
(0.039)\end{array}$ & $\begin{array}{c}-0.208^{* *} \\
(0.090)\end{array}$ & $\begin{array}{c}-0.169^{*} \\
(0.102)\end{array}$ \\
\hline Long-run & $\begin{array}{c}-0.173^{* * *} \\
(0.032)\end{array}$ & $\begin{array}{c}-0.218^{* * *} \\
(0.033)\end{array}$ & $\begin{array}{c}-0.187^{* * *} \\
(0.032)\end{array}$ & $\begin{array}{c}-0.310^{* * *} \\
(0.059)\end{array}$ & $\begin{array}{c}-0.498^{* * *} \\
(0.068)\end{array}$ \\
\hline \multicolumn{6}{|c|}{ Labor demand model (omitted: Conditional/Reduced-form) } \\
\hline Conditional/Structural-form & $\begin{array}{c}0.024 \\
(0.033)\end{array}$ & $\begin{array}{c}0.017 \\
(0.044)\end{array}$ & $\begin{array}{l}-0.016 \\
(0.042)\end{array}$ & $\begin{array}{c}0.156^{* *} \\
(0.069)\end{array}$ & $\begin{array}{c}0.004 \\
(0.089)\end{array}$ \\
\hline Unconditional/Reduced-form & $\begin{array}{l}-0.031 \\
(0.034)\end{array}$ & $\begin{array}{l}-0.023 \\
(0.035)\end{array}$ & $\begin{array}{l}-0.002 \\
(0.034)\end{array}$ & $\begin{array}{l}-0.027 \\
(0.041)\end{array}$ & $\begin{array}{c}-0.021 \\
(0.059)\end{array}$ \\
\hline Unconditional/Structural-form & $\begin{array}{l}-0.067 \\
(0.246)\end{array}$ & $\begin{array}{l}-0.084 \\
(0.190)\end{array}$ & $\begin{array}{l}-0.103 \\
(0.182)\end{array}$ & $\begin{array}{c}0.083 \\
(0.170)\end{array}$ & $\begin{array}{c}0.285 \\
(0.244)\end{array}$ \\
\hline Instrumenting wages & $\begin{array}{c}-0.073^{* *} \\
(0.033)\end{array}$ & $\begin{array}{c}-0.086^{* *} \\
(0.035)\end{array}$ & $\begin{array}{l}-0.043 \\
(0.034)\end{array}$ & $\begin{array}{c}-0.229^{* * *} \\
(0.071)\end{array}$ & $\begin{array}{c}-0.306^{* * *} \\
(0.094)\end{array}$ \\
\hline \multicolumn{6}{|l|}{ Dataset } \\
\hline \multicolumn{6}{|l|}{ Panel data specification (omitted: No panel data) } \\
\hline Panel data/No unit-fixed effects & $\begin{array}{c}0.147^{* * *} \\
(0.052)\end{array}$ & $\begin{array}{l}-0.131 \\
(0.081)\end{array}$ & $\begin{array}{c}-0.144^{*} \\
(0.078)\end{array}$ & $\begin{array}{c}0.013 \\
(0.126)\end{array}$ & $\begin{array}{c}0.056 \\
(0.189)\end{array}$ \\
\hline Panel data/Unit-fixed effects & $\begin{array}{c}0.047 \\
(0.046)\end{array}$ & $\begin{array}{c}-0.182^{* *} \\
(0.077)\end{array}$ & $\begin{array}{c}-0.184^{* *} \\
(0.074)\end{array}$ & $\begin{array}{l}-0.013 \\
(0.114)\end{array}$ & $\begin{array}{c}0.056 \\
(0.136)\end{array}$ \\
\hline Administrative data & $\begin{array}{c}0.029 \\
(0.031)\end{array}$ & $\begin{array}{c}0.020 \\
(0.047)\end{array}$ & $\begin{array}{l}-0.013 \\
(0.045)\end{array}$ & $\begin{array}{c}0.024 \\
(0.078)\end{array}$ & $\begin{array}{c}0.043 \\
(0.098)\end{array}$ \\
\hline Industry level data & $\begin{array}{c}0.046 \\
(0.031)\end{array}$ & $\begin{array}{c}0.052 \\
(0.043)\end{array}$ & $\begin{array}{c}0.064 \\
(0.041)\end{array}$ & $\begin{array}{l}0.110^{*} \\
(0.063)\end{array}$ & $\begin{array}{c}0.207^{* *} \\
(0.082)\end{array}$ \\
\hline \multicolumn{6}{|l|}{ Workforce characteristics } \\
\hline \multicolumn{6}{|l|}{ Skill level (omitted: All workers) } \\
\hline High-skilled workers & $\begin{array}{l}-0.012 \\
(0.050)\end{array}$ & $\begin{array}{c}0.012 \\
(0.044)\end{array}$ & $\begin{array}{c}0.052 \\
(0.042)\end{array}$ & $\begin{array}{c}-0.258^{* *} \\
(0.107)\end{array}$ & $\begin{array}{l}-0.173 \\
(0.145)\end{array}$ \\
\hline Unskilled workers & $\begin{array}{l}-0.064 \\
(0.040)\end{array}$ & $\begin{array}{c}-0.114^{* * *} \\
(0.034)\end{array}$ & $\begin{array}{c}-0.068^{* *} \\
(0.033)\end{array}$ & $\begin{array}{c}-0.197^{* *} \\
(0.081)\end{array}$ & $\begin{array}{c}-0.186^{*} \\
(0.096)\end{array}$ \\
\hline Demand for female workers & $\begin{array}{c}-0.223^{* * *} \\
(0.086)\end{array}$ & $\begin{array}{c}-0.271^{* * *} \\
(0.079)\end{array}$ & $\begin{array}{c}-0.204^{* * *} \\
(0.077)\end{array}$ & $\begin{array}{c}-1.193^{*} \\
(0.667)\end{array}$ & $\begin{array}{c}-1.039^{* *} \\
(0.513)\end{array}$ \\
\hline Atypical employment & $\begin{array}{c}-0.404^{* * *} \\
(0.054)\end{array}$ & $\begin{array}{c}-0.402^{* * *} \\
(0.049)\end{array}$ & $\begin{array}{c}-0.367^{* * *} \\
(0.047)\end{array}$ & $\begin{array}{c}-0.479^{* *} \\
(0.197)\end{array}$ & $\begin{array}{c}-0.564^{* * *} \\
(0.187)\end{array}$ \\
\hline Estimates' mean year of observation (centralized) & & $\begin{array}{c}-0.016^{* * *} \\
(0.003)\end{array}$ & $\begin{array}{c}-0.016^{* * *} \\
(0.002)\end{array}$ & $\begin{array}{c}-0.014^{* * *} \\
(0.005)\end{array}$ & $\begin{array}{c}-0.014^{* * *} \\
(0.004)\end{array}$ \\
\hline \multicolumn{6}{|l|}{ Publication selection bias } \\
\hline Standard error & & & $\begin{array}{c}-0.993^{* * *} \\
(0.134)\end{array}$ & & \\
\hline Industry dummy variables & No & Yes & Yes & Yes & Yes \\
\hline Year of publication dummy variables & No & Yes & Yes & Yes & Yes \\
\hline Country dummy variables & No & Yes & Yes & Yes & Yes \\
\hline No. of observation & 924 & 924 & 924 & 924 & 1560 \\
\hline Estimated between-study variance $\left(\tau^{2}\right)$ & 0.021 & 0.009 & 0.009 & - & - \\
\hline Adjusted R-Squared & 0.428 & 0.747 & 0.758 & 0.307 & 0.272 \\
\hline
\end{tabular}

Note: As regards to the results displayed in columns (1) to (3), the between-study variance $\tau^{2}$ is estimated by means of method of moments. Standard errors (in parentheses) of columns (4) and (5) are clustered at the study level. Significance levels are $0.1\left(^{*}\right), 0.05(* *)$, and $0.01(* * *)$. 


\section{B Appendix (For Online Publication)}

Table B.1: Full meta-regression analysis results

\begin{tabular}{|c|c|c|c|c|c|c|}
\hline Full regression results for: & $\begin{array}{c}\text { Tab. } 2 \\
\text { Column (5) }\end{array}$ & $\begin{array}{l}\text { Tab. } 3 \\
\text { Column (1) }\end{array}$ & $\begin{array}{c}\text { Tab. } 3 \\
\text { Column (2) }\end{array}$ & $\begin{array}{l}\text { Tab. } 3 \\
\text { Column (3) }\end{array}$ & $\begin{array}{c}\text { Tab. } 3 \\
\text { Column (4) }\end{array}$ & $\begin{array}{l}\text { Tab. } 3 \\
\text { Column (5) }\end{array}$ \\
\hline Constant & $\begin{array}{c}-0.428^{* *} \\
(0.183)\end{array}$ & $\begin{array}{c}-0.452^{* * *} \\
(0.164)\end{array}$ & $\begin{array}{c}-0.415^{* *} \\
(0.161)\end{array}$ & $\begin{array}{c}-0.436^{* * *} \\
(0.164)\end{array}$ & $\begin{array}{c}-0.488^{* * *} \\
(0.176)\end{array}$ & $\begin{array}{c}-0.466^{* * *} \\
(0.175)\end{array}$ \\
\hline \multicolumn{7}{|l|}{ Specification } \\
\hline \multicolumn{7}{|l|}{ Time period (omitted: Short-run) } \\
\hline Intermediate-run & $\begin{array}{c}-0.113^{* * *} \\
(0.042)\end{array}$ & $\begin{array}{c}-0.086^{* *} \\
(0.035)\end{array}$ & $\begin{array}{c}-0.077^{* *} \\
(0.032)\end{array}$ & $\begin{array}{c}-0.112^{* *} \\
(0.048)\end{array}$ & $\begin{array}{c}-0.079^{* *} \\
(0.033)\end{array}$ & $\begin{array}{c}-0.100^{* *} \\
(0.045)\end{array}$ \\
\hline Long-run & $\begin{array}{c}-0.127^{* * *} \\
(0.039)\end{array}$ & $\begin{array}{c}-0.102^{* *} \\
(0.039)\end{array}$ & $\begin{array}{l}-0.081^{*} \\
(0.043)\end{array}$ & $\begin{array}{c}-0.132^{* * *} \\
(0.045)\end{array}$ & $\begin{array}{c}-0.091^{* *} \\
(0.040)\end{array}$ & $\begin{array}{c}-0.118^{* *} \\
(0.046)\end{array}$ \\
\hline \multicolumn{7}{|l|}{ Model (omitted: Conditional/Reduced-form) } \\
\hline Conditional/Structural-form & $\begin{array}{l}-0.047 \\
(0.070)\end{array}$ & $\begin{array}{l}-0.036 \\
(0.069)\end{array}$ & $\begin{array}{c}0.029 \\
(0.084)\end{array}$ & $\begin{array}{l}-0.038 \\
(0.070)\end{array}$ & $\begin{array}{l}-0.087 \\
(0.071)\end{array}$ & $\begin{array}{l}-0.075 \\
(0.072)\end{array}$ \\
\hline Unconditional/Reduced-form & $\begin{array}{l}-0.018 \\
(0.052)\end{array}$ & $\begin{array}{l}-0.005 \\
(0.053)\end{array}$ & $\begin{array}{l}-0.007 \\
(0.053)\end{array}$ & $\begin{array}{l}-0.004 \\
(0.054)\end{array}$ & $\begin{array}{l}-0.002 \\
(0.055)\end{array}$ & $\begin{array}{l}-0.002 \\
(0.055)\end{array}$ \\
\hline Unconditional/Structural-form & $\begin{array}{l}-0.137 \\
(0.110)\end{array}$ & $\begin{array}{l}-0.119 \\
(0.107)\end{array}$ & $\begin{array}{l}-0.112 \\
(0.097)\end{array}$ & $\begin{array}{l}-0.117 \\
(0.108)\end{array}$ & $\begin{array}{l}-0.170 \\
(0.107)\end{array}$ & $\begin{array}{l}-0.155 \\
(0.110)\end{array}$ \\
\hline Instrumenting wages & $\begin{array}{c}0.029 \\
(0.035)\end{array}$ & $\begin{array}{c}0.032 \\
(0.035)\end{array}$ & $\begin{array}{c}0.033 \\
(0.035)\end{array}$ & $\begin{array}{c}0.033 \\
(0.035)\end{array}$ & $\begin{array}{c}0.032 \\
(0.035)\end{array}$ & $\begin{array}{c}0.033 \\
(0.035)\end{array}$ \\
\hline \multicolumn{7}{|l|}{ Dataset } \\
\hline \multicolumn{7}{|l|}{ Panel data specification (omitted: No panel data) } \\
\hline Panel data/No unit-fixed effects & $\begin{array}{l}-0.184 \\
(0.115)\end{array}$ & $\begin{array}{l}-0.168 \\
(0.116)\end{array}$ & $\begin{array}{l}-0.132 \\
(0.112)\end{array}$ & $\begin{array}{l}-0.149 \\
(0.116)\end{array}$ & $\begin{array}{l}-0.178 \\
(0.114)\end{array}$ & $\begin{array}{l}-0.161 \\
(0.114)\end{array}$ \\
\hline Panel data/Unit-fixed effects & $\begin{array}{l}-0.162 \\
(0.11)\end{array}$ & $\begin{array}{l}-0.145 \\
(0.114)\end{array}$ & $\begin{array}{l}-0.110 \\
(0.111)\end{array}$ & $\begin{array}{l}-0.124 \\
(0.114)\end{array}$ & $\begin{array}{l}-0.155 \\
(0.111)\end{array}$ & $\begin{array}{l}-0.136 \\
(0.112)\end{array}$ \\
\hline Administrative data & $\begin{array}{c}0.231^{* * *} \\
(0.079)\end{array}$ & $\begin{array}{l}0.204^{* *} \\
(0.080)\end{array}$ & $\begin{array}{c}0.218^{* * *} \\
(0.074)\end{array}$ & $\begin{array}{c}0.205^{* * *} \\
(0.075)\end{array}$ & $\begin{array}{c}0.206^{* * *} \\
(0.076)\end{array}$ & $\begin{array}{c}0.206^{* * *} \\
(0.074)\end{array}$ \\
\hline Industry level data & $\begin{array}{c}-0.086^{*} \\
(0.051)\end{array}$ & $\begin{array}{l}-0.072 \\
(0.049)\end{array}$ & $\begin{array}{c}-0.089^{*} \\
(0.049)\end{array}$ & $\begin{array}{c}-0.079^{*} \\
(0.043)\end{array}$ & $\begin{array}{c}-0.077^{*} \\
(0.046)\end{array}$ & $\begin{array}{c}-0.081^{*} \\
(0.042)\end{array}$ \\
\hline \multicolumn{7}{|l|}{ Workforce characteristics } \\
\hline High-skilled workers & $\begin{array}{c}0.018 \\
(0.075)\end{array}$ & $\begin{array}{c}0.029 \\
(0.080)\end{array}$ & $\begin{array}{c}0.019 \\
(0.081)\end{array}$ & $\begin{array}{c}0.031 \\
(0.078)\end{array}$ & $\begin{array}{c}0.027 \\
(0.077)\end{array}$ & $\begin{array}{c}0.029 \\
(0.076)\end{array}$ \\
\hline Unskilled workers & $\begin{array}{c}-0.207^{* * *} \\
(0.035)\end{array}$ & $\begin{array}{c}-0.197^{* * *} \\
(0.037)\end{array}$ & $\begin{array}{c}-0.195^{* * *} \\
(0.038)\end{array}$ & $\begin{array}{c}-0.195^{* * *} \\
(0.038)\end{array}$ & $\begin{array}{c}-0.201^{* * *} \\
(0.037)\end{array}$ & $\begin{array}{c}-0.198^{* * *} \\
(0.038)\end{array}$ \\
\hline Demand for female workers & $\begin{array}{c}-0.173^{* * *} \\
(0.030)\end{array}$ & $\begin{array}{c}-0.155^{* * *} \\
(0.026)\end{array}$ & $\begin{array}{c}-0.159^{* * *} \\
(0.026)\end{array}$ & $\begin{array}{c}-0.159^{* * *} \\
(0.027)\end{array}$ & $\begin{array}{c}-0.161^{* * *} \\
(0.024)\end{array}$ & $\begin{array}{c}-0.163^{* * *} \\
(0.025)\end{array}$ \\
\hline Atypical employment & $\begin{array}{c}-0.551^{* * *} \\
(0.047)\end{array}$ & $\begin{array}{c}-0.546^{* * *} \\
(0.063)\end{array}$ & $\begin{array}{c}-0.556^{* * *} \\
(0.059)\end{array}$ & $\begin{array}{c}-0.548^{* * *} \\
(0.058)\end{array}$ & $\begin{array}{c}-0.535^{* * *} \\
(0.061)\end{array}$ & $\begin{array}{c}-0.539^{* * *} \\
(0.058)\end{array}$ \\
\hline \multicolumn{7}{|l|}{$\begin{array}{l}\text { Industry (ISIC code) } \\
\text { (omitted: all industries) }\end{array}$} \\
\hline Mining (B) & $\begin{array}{l}-0.131 \\
(0.132)\end{array}$ & $\begin{array}{l}-0.007 \\
(0.126)\end{array}$ & $\begin{array}{c}0.084 \\
(0.138)\end{array}$ & $\begin{array}{c}0.044 \\
(0.128)\end{array}$ & $\begin{array}{c}0.010 \\
(0.122)\end{array}$ & $\begin{array}{c}0.045 \\
(0.126)\end{array}$ \\
\hline Manufacturing (C) & $\begin{array}{l}-0.092 \\
(0.080)\end{array}$ & $\begin{array}{l}-0.058 \\
(0.077)\end{array}$ & $\begin{array}{l}-0.055 \\
(0.072)\end{array}$ & $\begin{array}{l}-0.044 \\
(0.073)\end{array}$ & $\begin{array}{l}-0.051 \\
(0.074)\end{array}$ & $\begin{array}{l}-0.043 \\
(0.072)\end{array}$ \\
\hline Manufacture of food, beverages, tobacco (10-12) & $\begin{array}{l}0.302^{*} \\
(0.154)\end{array}$ & $\begin{array}{l}0.370^{* *} \\
(0.156)\end{array}$ & $\begin{array}{l}0.342^{* *} \\
(0.161)\end{array}$ & $\begin{array}{l}0.374^{* *} \\
(0.158)\end{array}$ & $\begin{array}{l}0.378^{* *} \\
(0.161)\end{array}$ & $\begin{array}{l}0.379^{* *} \\
(0.161)\end{array}$ \\
\hline Manufacture of textiles,apparel,leather (13-15) & $\begin{array}{c}0.172 \\
(0.203)\end{array}$ & $\begin{array}{c}0.262 \\
(0.213)\end{array}$ & $\begin{array}{c}0.228 \\
(0.221)\end{array}$ & $\begin{array}{c}0.259 \\
(0.214)\end{array}$ & $\begin{array}{c}0.274 \\
(0.221)\end{array}$ & $\begin{array}{c}0.269 \\
(0.220)\end{array}$ \\
\hline Manufacture of wood \& wood products (16) & $\begin{array}{c}0.167 \\
(0.198)\end{array}$ & $\begin{array}{c}0.210 \\
(0.147)\end{array}$ & $\begin{array}{c}0.190 \\
(0.150)\end{array}$ & $\begin{array}{c}0.219 \\
(0.159)\end{array}$ & $\begin{array}{c}0.239 \\
(0.184)\end{array}$ & $\begin{array}{c}0.238 \\
(0.185)\end{array}$ \\
\hline Manufacture of paper \& paper products (17) & $\begin{array}{c}0.033 \\
(0.128)\end{array}$ & $\begin{array}{c}0.154 \\
(0.114)\end{array}$ & $\begin{array}{c}0.115 \\
(0.103)\end{array}$ & $\begin{array}{c}0.144 \\
(0.114)\end{array}$ & $\begin{array}{c}0.168 \\
(0.101)\end{array}$ & $\begin{array}{c}0.156 \\
(0.105)\end{array}$ \\
\hline
\end{tabular}




\begin{tabular}{|c|c|c|c|c|c|c|}
\hline Printing (18) & $\begin{array}{l}-0.027 \\
(0.109)\end{array}$ & $\begin{array}{c}0.063 \\
(0.109)\end{array}$ & $\begin{array}{c}0.017 \\
(0.102)\end{array}$ & $\begin{array}{c}0.057 \\
(0.108)\end{array}$ & $\begin{array}{c}0.057 \\
(0.108)\end{array}$ & $\begin{array}{c}0.054 \\
(0.108)\end{array}$ \\
\hline Manufacture of coke \& petroleum (19) & $\begin{array}{c}0.121 \\
(0.113)\end{array}$ & $\begin{array}{l}0.206^{*} \\
(0.111)\end{array}$ & $\begin{array}{c}0.158 \\
(0.105)\end{array}$ & $\begin{array}{l}0.202^{*} \\
(0.110)\end{array}$ & $\begin{array}{l}0.203^{*} \\
(0.112)\end{array}$ & $\begin{array}{l}0.200^{*} \\
(0.111)\end{array}$ \\
\hline Manufacture of chemicals \& chemical products (20) & $\begin{array}{l}0.250 \\
(0.155)\end{array}$ & $\begin{array}{l}0.318^{* *} \\
(0.154)\end{array}$ & $\begin{array}{l}0.300^{*} \\
(0.162)\end{array}$ & $\begin{array}{c}0.324^{* *} \\
(0.157)\end{array}$ & $\begin{array}{l}0.328^{* *} \\
(0.159)\end{array}$ & $\begin{array}{c}0.330^{* *} \\
(0.160)\end{array}$ \\
\hline Manufacture of rubber \& plastic products (22) & $\begin{array}{c}0.050 \\
(0.106)\end{array}$ & $\begin{array}{c}0.173 \\
(0.110)\end{array}$ & $\begin{array}{c}0.127 \\
(0.100)\end{array}$ & $\begin{array}{c}0.160 \\
(0.109)\end{array}$ & $\begin{array}{c}0.148 \\
(0.107)\end{array}$ & $\begin{array}{c}0.144 \\
(0.106)\end{array}$ \\
\hline Manufacture of non-metallic mineral products (23) & $\begin{array}{l}-0.042 \\
(0.118)\end{array}$ & $\begin{array}{c}0.040 \\
(0.110)\end{array}$ & $\begin{array}{l}-0.006 \\
(0.103)\end{array}$ & $\begin{array}{c}0.037 \\
(0.110)\end{array}$ & $\begin{array}{c}0.049 \\
(0.107)\end{array}$ & $\begin{array}{c}0.044 \\
(0.108)\end{array}$ \\
\hline Manufacture of basic metals (24) & $\begin{array}{c}-0.331^{* *} \\
(0.135)\end{array}$ & $\begin{array}{l}-0.224 \\
(0.142)\end{array}$ & $\begin{array}{c}-0.241^{*} \\
(0.131)\end{array}$ & $\begin{array}{l}-0.227 \\
(0.138)\end{array}$ & $\begin{array}{l}-0.208 \\
(0.136)\end{array}$ & $\begin{array}{l}-0.214 \\
(0.134)\end{array}$ \\
\hline Manufacture of metal products $(25)$ & $\begin{array}{l}-0.119 \\
(0.085)\end{array}$ & $\begin{array}{l}-0.023 \\
(0.088)\end{array}$ & $\begin{array}{l}-0.041 \\
(0.085)\end{array}$ & $\begin{array}{l}-0.023 \\
(0.087)\end{array}$ & $\begin{array}{l}-0.003 \\
(0.091)\end{array}$ & $\begin{array}{l}-0.009 \\
(0.090)\end{array}$ \\
\hline Manufacture of electrical equipment (27) & $\begin{array}{c}0.241 \\
(0.174)\end{array}$ & $\begin{array}{l}0.344^{*} \\
(0.176)\end{array}$ & $\begin{array}{l}0.322^{*} \\
(0.183)\end{array}$ & $\begin{array}{l}0.339^{*} \\
(0.179)\end{array}$ & $\begin{array}{l}0.358^{*} \\
(0.183)\end{array}$ & $\begin{array}{l}0.350^{*} \\
(0.184)\end{array}$ \\
\hline Manufacture of machinery (28) & $\begin{array}{l}-0.015 \\
(0.082)\end{array}$ & $\begin{array}{c}0.096 \\
(0.087)\end{array}$ & $\begin{array}{c}0.080 \\
(0.081)\end{array}$ & $\begin{array}{c}0.093 \\
(0.085)\end{array}$ & $\begin{array}{c}0.129 \\
(0.088)\end{array}$ & $\begin{array}{c}0.118 \\
(0.086)\end{array}$ \\
\hline Manufacture of transport equipment (30) & $\begin{array}{c}0.080 \\
(0.095)\end{array}$ & $\begin{array}{l}0.180^{*} \\
(0.101)\end{array}$ & $\begin{array}{c}0.136 \\
(0.094)\end{array}$ & $\begin{array}{l}0.174^{*} \\
(0.098)\end{array}$ & $\begin{array}{l}0.196^{*} \\
(0.105)\end{array}$ & $\begin{array}{l}0.187^{*} \\
(0.103)\end{array}$ \\
\hline Other Manufacturing (32) & $\begin{array}{c}0.310^{* *} \\
(0.141)\end{array}$ & $\begin{array}{c}0.386^{* * *} \\
(0.143)\end{array}$ & $\begin{array}{c}0.360^{* *} \\
(0.148)\end{array}$ & $\begin{array}{c}0.389^{* * *} \\
(0.145)\end{array}$ & $\begin{array}{c}0.396^{* * *} \\
(0.150)\end{array}$ & $\begin{array}{c}0.395^{* * *} \\
(0.150)\end{array}$ \\
\hline Electricity, gas and water supply (D-E) & $\begin{array}{c}0.179 \\
(0.167)\end{array}$ & $\begin{array}{c}0.208 \\
(0.173)\end{array}$ & $\begin{array}{c}0.182 \\
(0.161)\end{array}$ & $\begin{array}{c}0.231 \\
(0.177)\end{array}$ & $\begin{array}{c}0.200 \\
(0.172)\end{array}$ & $\begin{array}{l}0.220 \\
(0.175)\end{array}$ \\
\hline Construction $(\mathrm{F})$ & $\begin{array}{l}-0.170 \\
(0.175)\end{array}$ & $\begin{array}{l}-0.071 \\
(0.150)\end{array}$ & $\begin{array}{l}-0.060 \\
(0.137)\end{array}$ & $\begin{array}{l}-0.070 \\
(0.154)\end{array}$ & $\begin{array}{l}-0.107 \\
(0.164)\end{array}$ & $\begin{array}{l}-0.097 \\
(0.162)\end{array}$ \\
\hline Wholesale (G) & $\begin{array}{l}0.299^{*} \\
(0.156)\end{array}$ & $\begin{array}{l}0.289^{*} \\
(0.157)\end{array}$ & $\begin{array}{c}0.245 \\
(0.148)\end{array}$ & $\begin{array}{l}0.311^{*} \\
(0.160)\end{array}$ & $\begin{array}{l}0.304^{*} \\
(0.158)\end{array}$ & $\begin{array}{l}0.316^{*} \\
(0.160)\end{array}$ \\
\hline Services (I-S) & $\begin{array}{l}-0.063 \\
(0.098)\end{array}$ & $\begin{array}{l}-0.035 \\
(0.086)\end{array}$ & $\begin{array}{l}-0.022 \\
(0.077)\end{array}$ & $\begin{array}{l}-0.019 \\
(0.082)\end{array}$ & $\begin{array}{l}-0.028 \\
(0.080)\end{array}$ & $\begin{array}{l}-0.018 \\
(0.079)\end{array}$ \\
\hline Information \& communication $(\mathrm{J})$ & $\begin{array}{l}-0.362 \\
(0.244)\end{array}$ & $\begin{array}{l}-0.347 \\
(0.212)\end{array}$ & $\begin{array}{l}-0.296 \\
(0.195)\end{array}$ & $\begin{array}{l}-0.290 \\
(0.219)\end{array}$ & $\begin{array}{l}-0.293 \\
(0.214)\end{array}$ & $\begin{array}{l}-0.264 \\
(0.218)\end{array}$ \\
\hline Financial \& insurance activities (K) & $\begin{array}{l}-0.053 \\
(0.156)\end{array}$ & $\begin{array}{c}0.117 \\
(0.169)\end{array}$ & $\begin{array}{c}0.103 \\
(0.171)\end{array}$ & $\begin{array}{c}0.095 \\
(0.173)\end{array}$ & $\begin{array}{c}0.024 \\
(0.169)\end{array}$ & $\begin{array}{c}0.033 \\
(0.171)\end{array}$ \\
\hline Country (omitted: Germany) & & & & & & \\
\hline Belgium & $\begin{array}{c}-0.415^{* * *} \\
(0.117)\end{array}$ & $\begin{array}{c}-0.343^{* * *} \\
(0.116)\end{array}$ & $\begin{array}{c}-0.265^{* *} \\
(0.112)\end{array}$ & $\begin{array}{c}-0.302^{* *} \\
(0.123)\end{array}$ & $\begin{array}{c}-0.329^{* * *} \\
(0.117)\end{array}$ & $\begin{array}{c}-0.301^{* *} \\
(0.124)\end{array}$ \\
\hline Denmark & $\begin{array}{c}-0.474^{* * *} \\
(0.070)\end{array}$ & $\begin{array}{c}-0.319^{* * *} \\
(0.076)\end{array}$ & $\begin{array}{c}-0.233^{* * *} \\
(0.082)\end{array}$ & $\begin{array}{l}-0.170 \\
(0.106)\end{array}$ & $\begin{array}{c}-0.252^{* * *} \\
(0.072)\end{array}$ & $\begin{array}{l}-0.156 \\
(0.106)\end{array}$ \\
\hline Finland & $\begin{array}{c}-0.153^{* *} \\
(0.070)\end{array}$ & $\begin{array}{l}0.197^{*} \\
(0.107)\end{array}$ & $\begin{array}{c}0.237^{* *} \\
(0.114)\end{array}$ & $\begin{array}{c}0.535^{* *} \\
(0.217)\end{array}$ & $\begin{array}{c}0.344^{* * *} \\
(0.112)\end{array}$ & $\begin{array}{c}0.565^{* *} \\
(0.217)\end{array}$ \\
\hline France & $\begin{array}{l}-0.076 \\
(0.091)\end{array}$ & $\begin{array}{l}-0.038 \\
(0.086)\end{array}$ & $\begin{array}{l}-0.003 \\
(0.076)\end{array}$ & $\begin{array}{l}-0.026 \\
(0.082)\end{array}$ & $\begin{array}{l}-0.025 \\
(0.083)\end{array}$ & $\begin{array}{l}-0.019 \\
(0.081)\end{array}$ \\
\hline Italy & $\begin{array}{c}-0.159^{* *} \\
(0.067)\end{array}$ & $\begin{array}{c}-0.134^{* *} \\
(0.065)\end{array}$ & $\begin{array}{l}-0.112^{*} \\
(0.061)\end{array}$ & $\begin{array}{l}-0.125^{*} \\
(0.064)\end{array}$ & $\begin{array}{l}-0.123^{*} \\
(0.063)\end{array}$ & $\begin{array}{c}-0.119^{*} \\
(0.063)\end{array}$ \\
\hline Netherlands & $\begin{array}{l}-0.259 \\
(0.306)\end{array}$ & $\begin{array}{l}-0.229 \\
(0.285)\end{array}$ & $\begin{array}{l}-0.215 \\
(0.299)\end{array}$ & $\begin{array}{l}-0.166 \\
(0.304)\end{array}$ & $\begin{array}{l}-0.176 \\
(0.302)\end{array}$ & $\begin{array}{l}-0.142 \\
(0.313)\end{array}$ \\
\hline Norway & $\begin{array}{l}-0.187 \\
(0.228)\end{array}$ & $\begin{array}{l}-0.165 \\
(0.209)\end{array}$ & $\begin{array}{l}-0.093 \\
(0.178)\end{array}$ & $\begin{array}{l}-0.136 \\
(0.191)\end{array}$ & $\begin{array}{l}-0.168 \\
(0.192)\end{array}$ & $\begin{array}{l}-0.145 \\
(0.183)\end{array}$ \\
\hline Spain & $\begin{array}{c}-0.170^{* *} \\
(0.086)\end{array}$ & $\begin{array}{l}-0.100 \\
(0.078)\end{array}$ & $\begin{array}{l}-0.067 \\
(0.078)\end{array}$ & $\begin{array}{l}-0.063 \\
(0.073)\end{array}$ & $\begin{array}{l}-0.072 \\
(0.074)\end{array}$ & $\begin{array}{l}-0.051 \\
(0.072)\end{array}$ \\
\hline Sweden & $\begin{array}{l}-0.053 \\
(0.061)\end{array}$ & $\begin{array}{l}-0.044 \\
(0.058)\end{array}$ & $\begin{array}{l}-0.024 \\
(0.059)\end{array}$ & $\begin{array}{l}-0.050 \\
(0.056)\end{array}$ & $\begin{array}{l}-0.042 \\
(0.055)\end{array}$ & $\begin{array}{l}-0.047 \\
(0.054)\end{array}$ \\
\hline UK & $\begin{array}{c}-0.275^{* *} \\
(0.121)\end{array}$ & $\begin{array}{c}-0.241^{*} \\
(0.126)\end{array}$ & $\begin{array}{l}-0.154 \\
(0.122)\end{array}$ & $\begin{array}{l}-0.226^{*} \\
(0.125)\end{array}$ & $\begin{array}{l}-0.227^{*} \\
(0.125)\end{array}$ & $\begin{array}{c}-0.219^{*} \\
(0.124)\end{array}$ \\
\hline Ireland & $\begin{array}{c}-0.316^{* *} \\
(0.153)\end{array}$ & $\begin{array}{c}-0.324^{* *} \\
(0.153)\end{array}$ & $\begin{array}{l}-0.200 \\
(0.141)\end{array}$ & $\begin{array}{c}-0.336^{* *} \\
(0.152)\end{array}$ & $\begin{array}{c}-0.321^{* *} \\
(0.150)\end{array}$ & $\begin{array}{c}-0.331^{* *} \\
(0.151)\end{array}$ \\
\hline Turkey & $\begin{array}{c}-0.621^{* * *} \\
(0.119)\end{array}$ & $\begin{array}{c}-0.658^{* * *} \\
(0.112)\end{array}$ & $\begin{array}{c}-0.522^{* * *} \\
(0.139)\end{array}$ & $\begin{array}{c}-0.667^{* * *} \\
(0.119)\end{array}$ & $\begin{array}{c}-0.684^{* * *} \\
(0.110)\end{array}$ & $\begin{array}{r}-0.684^{* * *} \\
(0.117)\end{array}$ \\
\hline
\end{tabular}




\begin{tabular}{|c|c|c|c|c|c|c|}
\hline Japan & $\begin{array}{l}-0.049 \\
(0.079)\end{array}$ & $\begin{array}{l}-0.032 \\
(0.074)\end{array}$ & $\begin{array}{l}-0.006 \\
(0.071)\end{array}$ & $\begin{array}{l}-0.033 \\
(0.072)\end{array}$ & $\begin{array}{l}-0.026 \\
(0.072)\end{array}$ & $\begin{array}{l}-0.029 \\
(0.072)\end{array}$ \\
\hline United States & $\begin{array}{l}-0.053 \\
(0.088)\end{array}$ & $\begin{array}{l}-0.035 \\
(0.087)\end{array}$ & $\begin{array}{l}-0.012 \\
(0.085)\end{array}$ & $\begin{array}{l}-0.034 \\
(0.088)\end{array}$ & $\begin{array}{l}-0.026 \\
(0.086)\end{array}$ & $\begin{array}{l}-0.028 \\
(0.087)\end{array}$ \\
\hline Portugal & $\begin{array}{l}-0.267^{*} \\
(0.146)\end{array}$ & $\begin{array}{l}-0.204 \\
(0.143)\end{array}$ & $\begin{array}{l}-0.146 \\
(0.143)\end{array}$ & $\begin{array}{l}-0.180 \\
(0.144)\end{array}$ & $\begin{array}{l}-0.194 \\
(0.143)\end{array}$ & $\begin{array}{l}-0.179 \\
(0.144)\end{array}$ \\
\hline Colombia & $\begin{array}{c}0.147 \\
(0.121)\end{array}$ & $\begin{array}{c}0.126 \\
(0.121)\end{array}$ & $\begin{array}{l}0.203^{*} \\
(0.114)\end{array}$ & $\begin{array}{c}0.108 \\
(0.118)\end{array}$ & $\begin{array}{c}0.110 \\
(0.123)\end{array}$ & $\begin{array}{c}0.101 \\
(0.120)\end{array}$ \\
\hline Tunesia & $\begin{array}{c}-0.437^{* *} \\
(0.194)\end{array}$ & $\begin{array}{c}-0.484^{* *} \\
(0.186)\end{array}$ & $\begin{array}{l}-0.367^{*} \\
(0.219)\end{array}$ & $\begin{array}{c}-0.491^{* *} \\
(0.197)\end{array}$ & $\begin{array}{c}-0.479^{* *} \\
(0.188)\end{array}$ & $\begin{array}{c}-0.486^{* *} \\
(0.196)\end{array}$ \\
\hline Uruguay & $\begin{array}{l}-0.026 \\
(0.110)\end{array}$ & $\begin{array}{l}-0.018 \\
(0.111)\end{array}$ & $\begin{array}{c}0.049 \\
(0.120)\end{array}$ & $\begin{array}{l}-0.013 \\
(0.106)\end{array}$ & $\begin{array}{l}-0.018 \\
(0.111)\end{array}$ & $\begin{array}{l}-0.014 \\
(0.108)\end{array}$ \\
\hline Peru & $\begin{array}{c}0.207^{* *} \\
(0.104)\end{array}$ & $\begin{array}{c}0.221^{* *} \\
(0.101)\end{array}$ & $\begin{array}{c}0.295^{* *} \\
(0.113)\end{array}$ & $\begin{array}{c}0.219^{* *} \\
(0.099)\end{array}$ & $\begin{array}{c}0.212^{* *} \\
(0.103)\end{array}$ & $\begin{array}{c}0.213^{* *} \\
(0.101)\end{array}$ \\
\hline Chile & $\begin{array}{c}0.186 \\
(0.128)\end{array}$ & $\begin{array}{l}0.209 \\
(0.127)\end{array}$ & $\begin{array}{l}0.292^{* *} \\
(0.119)\end{array}$ & $\begin{array}{c}0.187 \\
(0.129)\end{array}$ & $\begin{array}{l}0.230^{*} \\
(0.122)\end{array}$ & $\begin{array}{c}0.207 \\
(0.125)\end{array}$ \\
\hline Mexico & $\begin{array}{c}0.368^{* * *} \\
(0.137)\end{array}$ & $\begin{array}{c}0.321^{* *} \\
(0.135)\end{array}$ & $\begin{array}{c}0.500^{* * *} \\
(0.150)\end{array}$ & $\begin{array}{c}0.311^{* *} \\
(0.142)\end{array}$ & $\begin{array}{l}0.287^{* *} \\
(0.138)\end{array}$ & $\begin{array}{c}0.288^{* *} \\
(0.142)\end{array}$ \\
\hline Argentina & $\begin{array}{c}0.140 \\
(0.121)\end{array}$ & $\begin{array}{c}0.119 \\
(0.121)\end{array}$ & $\begin{array}{c}0.191 \\
(0.116)\end{array}$ & $\begin{array}{c}0.104 \\
(0.117)\end{array}$ & $\begin{array}{c}0.105 \\
(0.123)\end{array}$ & $\begin{array}{c}0.097 \\
(0.119)\end{array}$ \\
\hline Macedonia & $\begin{array}{c}-0.636^{* * *} \\
(0.105)\end{array}$ & $\begin{array}{c}-0.550^{* * *} \\
(0.108)\end{array}$ & $\begin{array}{c}-0.480^{* * *} \\
(0.114)\end{array}$ & $\begin{array}{c}-0.493^{* * *} \\
(0.113)\end{array}$ & $\begin{array}{c}-0.526^{* * *} \\
(0.104)\end{array}$ & $\begin{array}{c}-0.488^{* * *} \\
(0.111)\end{array}$ \\
\hline India & $\begin{array}{c}0.166 \\
(0.153)\end{array}$ & $\begin{array}{c}0.185 \\
(0.144)\end{array}$ & $\begin{array}{l}0.360^{*} \\
(0.191)\end{array}$ & $\begin{array}{c}0.157 \\
(0.153)\end{array}$ & $\begin{array}{c}0.215 \\
(0.141)\end{array}$ & $\begin{array}{c}0.185 \\
(0.150)\end{array}$ \\
\hline China & $\begin{array}{c}0.145 \\
(0.133)\end{array}$ & $\begin{array}{c}0.191 \\
(0.130)\end{array}$ & $\begin{array}{c}0.251^{* *} \\
(0.120)\end{array}$ & $\begin{array}{c}0.247^{* *} \\
(0.118)\end{array}$ & $\begin{array}{l}0.222^{*} \\
(0.119)\end{array}$ & $\begin{array}{c}0.257^{* *} \\
(0.115)\end{array}$ \\
\hline Czech Republic & $\begin{array}{c}-0.518^{* * *} \\
(0.108)\end{array}$ & $\begin{array}{c}-0.232^{*} \\
(0.122)\end{array}$ & $\begin{array}{l}-0.189 \\
(0.131)\end{array}$ & $\begin{array}{l}-0.051 \\
(0.157)\end{array}$ & $\begin{array}{l}-0.117 \\
(0.130)\end{array}$ & $\begin{array}{l}-0.008 \\
(0.159)\end{array}$ \\
\hline Slovak Republic & $\begin{array}{l}-0.088 \\
(0.136)\end{array}$ & $\begin{array}{c}0.101 \\
(0.161)\end{array}$ & $\begin{array}{c}0.146 \\
(0.175)\end{array}$ & $\begin{array}{c}0.260 \\
(0.203)\end{array}$ & $\begin{array}{c}0.177 \\
(0.173)\end{array}$ & $\begin{array}{c}0.279 \\
(0.206)\end{array}$ \\
\hline Poland & $\begin{array}{c}-0.457^{* * *} \\
(0.106)\end{array}$ & $\begin{array}{c}-0.450^{* * *} \\
(0.104)\end{array}$ & $\begin{array}{c}-0.434^{* * *} \\
(0.095)\end{array}$ & $\begin{array}{c}-0.456^{* * *} \\
(0.102)\end{array}$ & $\begin{array}{c}-0.450^{* * *} \\
(0.103)\end{array}$ & $\begin{array}{c}-0.455^{* * *} \\
(0.102)\end{array}$ \\
\hline Hungary & $\begin{array}{c}-0.350^{* * *} \\
(0.104)\end{array}$ & $\begin{array}{l}-0.039 \\
(0.122)\end{array}$ & $\begin{array}{c}0.011 \\
(0.135)\end{array}$ & $\begin{array}{c}0.174 \\
(0.175)\end{array}$ & $\begin{array}{c}0.087 \\
(0.133)\end{array}$ & $\begin{array}{c}0.217 \\
(0.174)\end{array}$ \\
\hline South Korea & $\begin{array}{c}0.190^{* *} \\
(0.093)\end{array}$ & $\begin{array}{c}0.140 \\
(0.089)\end{array}$ & $\begin{array}{l}0.143^{*} \\
(0.083)\end{array}$ & $\begin{array}{c}0.134 \\
(0.091)\end{array}$ & $\begin{array}{c}0.132 \\
(0.086)\end{array}$ & $\begin{array}{c}0.129 \\
(0.089)\end{array}$ \\
\hline Slovenia & $\begin{array}{c}0.949^{* * *} \\
(0.089)\end{array}$ & $\begin{array}{c}2.069^{* * *} \\
(0.290)\end{array}$ & $\begin{array}{c}2.300^{* * *} \\
(0.440)\end{array}$ & $\begin{array}{c}3.163^{* * *} \\
(0.700)\end{array}$ & $\begin{array}{c}2.542^{* * *} \\
(0.356)\end{array}$ & $\begin{array}{c}3.257^{* * *} \\
(0.703)\end{array}$ \\
\hline Bulgaria & $\begin{array}{c}1.064^{* * *} \\
(0.083)\end{array}$ & $\begin{array}{c}2.684^{* * *} \\
(0.417)\end{array}$ & $\begin{array}{c}2.991^{* * *} \\
(0.640)\end{array}$ & $\begin{array}{c}4.259^{* * *} \\
(1.014)\end{array}$ & $\begin{array}{c}3.359^{* * *} \\
(0.514)\end{array}$ & $\begin{array}{c}4.391^{* * *} \\
(1.018)\end{array}$ \\
\hline Romania & $\begin{array}{c}0.307^{* * *} \\
(0.089)\end{array}$ & $\begin{array}{c}0.766^{* * *} \\
(0.135)\end{array}$ & $\begin{array}{c}0.896^{* * *} \\
(0.187)\end{array}$ & $\begin{array}{c}1.219^{* * *} \\
(0.288)\end{array}$ & $\begin{array}{c}0.966^{* * *} \\
(0.158)\end{array}$ & $\begin{array}{c}1.261^{* * *} \\
(0.290)\end{array}$ \\
\hline Lithuania & $\begin{array}{c}0.082 \\
(0.100)\end{array}$ & $\begin{array}{l}0.191^{*} \\
(0.102)\end{array}$ & $\begin{array}{l}0.254^{* *} \\
(0.114)\end{array}$ & $\begin{array}{l}0.171^{*} \\
(0.100)\end{array}$ & $\begin{array}{l}0.238^{* *} \\
(0.103)\end{array}$ & $\begin{array}{l}0.210^{* *} \\
(0.100)\end{array}$ \\
\hline Mauritius & $\begin{array}{c}-0.290^{* *} \\
(0.118)\end{array}$ & $\begin{array}{l}-0.153 \\
(0.127)\end{array}$ & $\begin{array}{l}-0.064 \\
(0.152)\end{array}$ & $\begin{array}{l}-0.065 \\
(0.130)\end{array}$ & $\begin{array}{l}-0.108 \\
(0.129)\end{array}$ & $\begin{array}{l}-0.053 \\
(0.132)\end{array}$ \\
\hline Canada & $\begin{array}{l}-0.269 \\
(0.214)\end{array}$ & $\begin{array}{l}-0.164 \\
(0.183)\end{array}$ & $\begin{array}{l}-0.271 \\
(0.182)\end{array}$ & $\begin{array}{l}-0.225 \\
(0.188)\end{array}$ & $\begin{array}{l}-0.237 \\
(0.185)\end{array}$ & $\begin{array}{l}-0.265 \\
(0.188)\end{array}$ \\
\hline Aggr. Europe & $\begin{array}{c}-0.197^{* *} \\
(0.095)\end{array}$ & $\begin{array}{c}-0.185^{* *} \\
(0.093)\end{array}$ & $\begin{array}{l}-0.152 \\
(0.112)\end{array}$ & $\begin{array}{l}-0.181^{*} \\
(0.094)\end{array}$ & $\begin{array}{l}-0.168^{*} \\
(0.096)\end{array}$ & $\begin{array}{l}-0.170^{*} \\
(0.096)\end{array}$ \\
\hline Aggr. Data & $\begin{array}{c}-0.293^{* * *} \\
(0.092)\end{array}$ & $\begin{array}{c}-0.232^{* *} \\
(0.100)\end{array}$ & $\begin{array}{l}-0.159 \\
(0.140)\end{array}$ & $\begin{array}{c}-0.248^{* *} \\
(0.097)\end{array}$ & $\begin{array}{l}-0.203^{*} \\
(0.108)\end{array}$ & $\begin{array}{c}-0.223^{* *} \\
(0.104)\end{array}$ \\
\hline Estimates' mean year of observation (centralized) & $\begin{array}{l}-0.008^{*} \\
(0.004)\end{array}$ & $\begin{array}{l}-0.007^{*} \\
(0.004)\end{array}$ & $\begin{array}{l}-0.006^{*} \\
(0.003)\end{array}$ & $\begin{array}{l}-0.007^{*} \\
(0.004)\end{array}$ & $\begin{array}{l}-0.007^{*} \\
(0.004)\end{array}$ & $\begin{array}{l}-0.007^{*} \\
(0.004)\end{array}$ \\
\hline \multicolumn{7}{|l|}{$\begin{array}{l}\text { Year of publication } \\
\text { (omitted: 1980) }\end{array}$} \\
\hline 1981 & $\begin{array}{c}0.415^{* * *} \\
(0.158)\end{array}$ & $\begin{array}{c}0.381^{* * *} \\
(0.135)\end{array}$ & $\begin{array}{c}0.359^{* * *} \\
(0.134)\end{array}$ & $\begin{array}{c}0.394^{* * *} \\
(0.138)\end{array}$ & $\begin{array}{c}0.446^{* * *} \\
(0.163)\end{array}$ & $\begin{array}{c}0.438^{* * *} \\
(0.161)\end{array}$ \\
\hline 1984 & $\begin{array}{c}0.122 \\
(0.218)\end{array}$ & $\begin{array}{c}0.097 \\
(0.207)\end{array}$ & $\begin{array}{c}0.050 \\
(0.190)\end{array}$ & $\begin{array}{c}0.075 \\
(0.213)\end{array}$ & $\begin{array}{c}0.162 \\
(0.226)\end{array}$ & $\begin{array}{c}0.128 \\
(0.226)\end{array}$ \\
\hline
\end{tabular}




\begin{tabular}{|c|c|c|c|c|c|c|}
\hline 1985 & $\begin{array}{l}-0.190 \\
(0.246)\end{array}$ & $\begin{array}{l}-0.139 \\
(0.230)\end{array}$ & $\begin{array}{l}-0.094 \\
(0.220)\end{array}$ & $\begin{array}{l}-0.098 \\
(0.236)\end{array}$ & $\begin{array}{l}-0.068 \\
(0.243)\end{array}$ & $\begin{array}{l}-0.056 \\
(0.244)\end{array}$ \\
\hline 1986 & $\begin{array}{c}0.111 \\
(0.220)\end{array}$ & $\begin{array}{c}0.021 \\
(0.177)\end{array}$ & $\begin{array}{c}0.027 \\
(0.163)\end{array}$ & $\begin{array}{c}0.033 \\
(0.184)\end{array}$ & $\begin{array}{c}0.111 \\
(0.217)\end{array}$ & $\begin{array}{c}0.096 \\
(0.213)\end{array}$ \\
\hline 1987 & $\begin{array}{c}0.284 \\
(0.227)\end{array}$ & $\begin{array}{l}0.382^{*} \\
(0.218)\end{array}$ & $\begin{array}{c}0.301 \\
(0.201)\end{array}$ & $\begin{array}{c}0.341 \\
(0.221)\end{array}$ & $\begin{array}{l}0.452^{*} \\
(0.234)\end{array}$ & $\begin{array}{l}0.402^{*} \\
(0.232)\end{array}$ \\
\hline 1988 & $\begin{array}{l}-0.031 \\
(0.156)\end{array}$ & $\begin{array}{l}-0.043 \\
(0.135)\end{array}$ & $\begin{array}{l}-0.080 \\
(0.130)\end{array}$ & $\begin{array}{l}-0.038 \\
(0.138)\end{array}$ & $\begin{array}{c}0.010 \\
(0.161)\end{array}$ & $\begin{array}{l}-0.000 \\
(0.159)\end{array}$ \\
\hline 1990 & $\begin{array}{c}0.740^{* * *} \\
(0.276)\end{array}$ & $\begin{array}{c}0.728^{* * *} \\
(0.271)\end{array}$ & $\begin{array}{c}0.694^{* * *} \\
(0.246)\end{array}$ & $\begin{array}{c}0.738^{* * *} \\
(0.278)\end{array}$ & $\begin{array}{c}0.785^{* * *} \\
(0.280)\end{array}$ & $\begin{array}{c}0.778^{* * *} \\
(0.283)\end{array}$ \\
\hline 1991 & $\begin{array}{c}0.238 \\
(0.273)\end{array}$ & $\begin{array}{c}0.298 \\
(0.264)\end{array}$ & $\begin{array}{c}0.296 \\
(0.238)\end{array}$ & $\begin{array}{c}0.334 \\
(0.271)\end{array}$ & $\begin{array}{c}0.367 \\
(0.273)\end{array}$ & $\begin{array}{c}0.376 \\
(0.276)\end{array}$ \\
\hline 1992 & $\begin{array}{c}-0.883^{* * *} \\
(0.143)\end{array}$ & $\begin{array}{c}-0.503^{* * *} \\
(0.155)\end{array}$ & $\begin{array}{c}-0.607^{* * *} \\
(0.148)\end{array}$ & $\begin{array}{c}-0.581^{* * *} \\
(0.155)\end{array}$ & $\begin{array}{c}-0.674^{* * *} \\
(0.159)\end{array}$ & $\begin{array}{c}-0.688^{* * *} \\
(0.159)\end{array}$ \\
\hline 1993 & $\begin{array}{l}0.309^{*} \\
(0.182)\end{array}$ & $\begin{array}{c}0.263 \\
(0.160)\end{array}$ & $\begin{array}{c}0.154 \\
(0.170)\end{array}$ & $\begin{array}{c}0.242 \\
(0.163)\end{array}$ & $\begin{array}{l}0.290 \\
(0.177)\end{array}$ & $\begin{array}{c}0.266 \\
(0.176)\end{array}$ \\
\hline 1994 & $\begin{array}{c}0.290 \\
(0.230)\end{array}$ & $\begin{array}{l}0.392^{*} \\
(0.220)\end{array}$ & $\begin{array}{l}0.359^{*} \\
(0.209)\end{array}$ & $\begin{array}{c}0.459^{* *} \\
(0.228)\end{array}$ & $\begin{array}{c}0.483^{* *} \\
(0.238)\end{array}$ & $\begin{array}{c}0.510^{* *} \\
(0.241)\end{array}$ \\
\hline 1995 & $\begin{array}{c}0.075 \\
(0.316)\end{array}$ & $\begin{array}{c}0.119 \\
(0.302)\end{array}$ & $\begin{array}{l}-0.051 \\
(0.284)\end{array}$ & $\begin{array}{c}0.066 \\
(0.291)\end{array}$ & $\begin{array}{c}0.176 \\
(0.311)\end{array}$ & $\begin{array}{c}0.119 \\
(0.301)\end{array}$ \\
\hline 1996 & $\begin{array}{l}-0.246 \\
(0.409)\end{array}$ & $\begin{array}{l}-0.080 \\
(0.377)\end{array}$ & $\begin{array}{l}-0.154 \\
(0.393)\end{array}$ & $\begin{array}{c}-0.140 \\
(0.391)\end{array}$ & $\begin{array}{l}-0.150 \\
(0.399)\end{array}$ & $\begin{array}{l}-0.176 \\
(0.404)\end{array}$ \\
\hline 1997 & $\begin{array}{c}0.298 \\
(0.289)\end{array}$ & $\begin{array}{c}0.302 \\
(0.281)\end{array}$ & $\begin{array}{c}0.195 \\
(0.258)\end{array}$ & $\begin{array}{c}0.284 \\
(0.288)\end{array}$ & $\begin{array}{c}0.374 \\
(0.299)\end{array}$ & $\begin{array}{c}0.340 \\
(0.300)\end{array}$ \\
\hline 1998 & $\begin{array}{c}0.308 \\
(0.219)\end{array}$ & $\begin{array}{c}0.290 \\
(0.202)\end{array}$ & $\begin{array}{c}0.223 \\
(0.200)\end{array}$ & $\begin{array}{c}0.285 \\
(0.207)\end{array}$ & $\begin{array}{c}0.343 \\
(0.222)\end{array}$ & $\begin{array}{c}0.324 \\
(0.221)\end{array}$ \\
\hline 1999 & $\begin{array}{c}0.617^{* * *} \\
(0.215)\end{array}$ & $\begin{array}{c}0.588^{* * *} \\
(0.202)\end{array}$ & $\begin{array}{c}0.451^{* *} \\
(0.198)\end{array}$ & $\begin{array}{c}0.563^{* * *} \\
(0.207)\end{array}$ & $\begin{array}{c}0.653^{* * *} \\
(0.221)\end{array}$ & $\begin{array}{c}0.617^{* * *} \\
(0.221)\end{array}$ \\
\hline 2000 & $\begin{array}{l}0.533^{*} \\
(0.305)\end{array}$ & $\begin{array}{c}0.436 \\
(0.276)\end{array}$ & $\begin{array}{c}0.306 \\
(0.248)\end{array}$ & $\begin{array}{c}0.442 \\
(0.280)\end{array}$ & $\begin{array}{l}0.549^{*} \\
(0.313)\end{array}$ & $\begin{array}{l}0.523^{*} \\
(0.307)\end{array}$ \\
\hline 2001 & $\begin{array}{c}0.600^{* *} \\
(0.237)\end{array}$ & $\begin{array}{c}0.614^{* * *} \\
(0.221)\end{array}$ & $\begin{array}{c}0.499^{* *} \\
(0.217)\end{array}$ & $\begin{array}{l}0.592^{* *} \\
(0.227)\end{array}$ & $\begin{array}{c}0.679^{* * *} \\
(0.240)\end{array}$ & $\begin{array}{c}0.645^{* * *} \\
(0.241)\end{array}$ \\
\hline 2002 & $\begin{array}{c}0.545^{* *} \\
(0.215)\end{array}$ & $\begin{array}{c}0.548^{* * *} \\
(0.200)\end{array}$ & $\begin{array}{c}0.471^{* *} \\
(0.195)\end{array}$ & $\begin{array}{c}0.527^{* *} \\
(0.205)\end{array}$ & $\begin{array}{c}0.604^{* * *} \\
(0.219)\end{array}$ & $\begin{array}{c}0.572^{* *} \\
(0.219)\end{array}$ \\
\hline 2003 & $\begin{array}{c}0.480^{* *} \\
(0.226)\end{array}$ & $\begin{array}{l}0.471^{* *} \\
(0.211)\end{array}$ & $\begin{array}{l}0.385^{*} \\
(0.202)\end{array}$ & $\begin{array}{l}0.444^{* *} \\
(0.215)\end{array}$ & $\begin{array}{l}0.517^{* *} \\
(0.228)\end{array}$ & $\begin{array}{c}0.483^{* *} \\
(0.227)\end{array}$ \\
\hline 2004 & $\begin{array}{l}0.441^{*} \\
(0.238)\end{array}$ & $\begin{array}{l}0.442^{* *} \\
(0.220)\end{array}$ & $\begin{array}{c}0.349 \\
(0.220)\end{array}$ & $\begin{array}{l}0.416^{*} \\
(0.225)\end{array}$ & $\begin{array}{c}0.500^{* *} \\
(0.240)\end{array}$ & $\begin{array}{l}0.464^{*} \\
(0.239)\end{array}$ \\
\hline 2005 & $\begin{array}{l}0.400^{*} \\
(0.226)\end{array}$ & $\begin{array}{l}0.409^{*} \\
(0.212)\end{array}$ & $\begin{array}{c}0.326 \\
(0.206)\end{array}$ & $\begin{array}{l}0.386^{*} \\
(0.215)\end{array}$ & $\begin{array}{c}0.456^{* *} \\
(0.228)\end{array}$ & $\begin{array}{l}0.425^{*} \\
(0.227)\end{array}$ \\
\hline 2006 & $\begin{array}{l}0.441^{*} \\
(0.242)\end{array}$ & $\begin{array}{c}0.469^{* *} \\
(0.230)\end{array}$ & $\begin{array}{l}0.375^{*} \\
(0.209)\end{array}$ & $\begin{array}{l}0.432^{*} \\
(0.230)\end{array}$ & $\begin{array}{l}0.514^{* *} \\
(0.243)\end{array}$ & $\begin{array}{l}0.473^{*} \\
(0.241)\end{array}$ \\
\hline 2007 & $\begin{array}{l}0.400^{*} \\
(0.215)\end{array}$ & $\begin{array}{c}0.393^{* *} \\
(0.196)\end{array}$ & $\begin{array}{c}0.243 \\
(0.218)\end{array}$ & $\begin{array}{l}0.385^{*} \\
(0.204)\end{array}$ & $\begin{array}{l}0.434^{* *} \\
(0.211)\end{array}$ & $\begin{array}{l}0.416^{*} \\
(0.213)\end{array}$ \\
\hline 2008 & $\begin{array}{l}0.413^{*} \\
(0.240)\end{array}$ & $\begin{array}{l}0.439^{*} \\
(0.227)\end{array}$ & $\begin{array}{c}0.303 \\
(0.221)\end{array}$ & $\begin{array}{l}0.421^{*} \\
(0.233)\end{array}$ & $\begin{array}{c}0.491^{* *} \\
(0.243)\end{array}$ & $\begin{array}{l}0.463^{*} \\
(0.245)\end{array}$ \\
\hline 2009 & $\begin{array}{c}0.755^{* * *} \\
(0.277)\end{array}$ & $\begin{array}{c}0.735^{* * *} \\
(0.268)\end{array}$ & $\begin{array}{l}0.568^{* *} \\
(0.256)\end{array}$ & $\begin{array}{c}0.697^{* *} \\
(0.275)\end{array}$ & $\begin{array}{c}0.772^{* * *} \\
(0.280)\end{array}$ & $\begin{array}{c}0.733^{* *} \\
(0.282)\end{array}$ \\
\hline 2010 & $\begin{array}{c}0.629^{* * *} \\
(0.213)\end{array}$ & $\begin{array}{c}0.661^{* * *} \\
(0.197)\end{array}$ & $\begin{array}{c}0.578^{* * *} \\
(0.188)\end{array}$ & $\begin{array}{c}0.641^{* * *} \\
(0.202)\end{array}$ & $\begin{array}{c}0.715^{* * *} \\
(0.213)\end{array}$ & $\begin{array}{c}0.685^{* * *} \\
(0.214)\end{array}$ \\
\hline 2011 & $\begin{array}{c}0.659^{* * *} \\
(0.214)\end{array}$ & $\begin{array}{c}0.666^{* * *} \\
(0.198)\end{array}$ & $\begin{array}{c}0.582^{* * *} \\
(0.190)\end{array}$ & $\begin{array}{c}0.637^{* * *} \\
(0.204)\end{array}$ & $\begin{array}{c}0.715^{* * *} \\
(0.213)\end{array}$ & $\begin{array}{c}0.679^{* * *} \\
(0.215)\end{array}$ \\
\hline 2012 & $\begin{array}{c}0.544^{* *} \\
(0.225)\end{array}$ & $\begin{array}{c}0.524^{* *} \\
(0.208)\end{array}$ & $\begin{array}{l}0.393^{*} \\
(0.216)\end{array}$ & $\begin{array}{l}0.508^{* *} \\
(0.216)\end{array}$ & $\begin{array}{c}0.589^{* *} \\
(0.226)\end{array}$ & $\begin{array}{c}0.560^{* *} \\
(0.228)\end{array}$ \\
\hline \multicolumn{7}{|l|}{ Publication Selection Bias } \\
\hline Standard error & & $\begin{array}{c}-1.218^{* * *} \\
(0.322)\end{array}$ & $\begin{array}{c}-1.418^{* * *} \\
(0.510)\end{array}$ & $\begin{array}{c}-0.930^{* * *} \\
(0.298)\end{array}$ & $\begin{array}{c}-1.720^{* * *} \\
(0.395)\end{array}$ & $\begin{array}{c}-1.363^{* * *} \\
(0.343)\end{array}$ \\
\hline Normalized impact factor & & & $\begin{array}{l}-0.198 \\
(0.146)\end{array}$ & & & \\
\hline Std. error*Normalized impact factor & & & 0.778 & & & \\
\hline
\end{tabular}


Std. error*Short-run elasticity

Std. error*Structural-form model

No. of observations

Adjusted R-Squared
(1.001)

$-1.470^{*}$

$-1.132$

(0.811)

(0.789)

$1.222^{* *} \quad 0.893^{*}$

(0.566) (0.518)

Note: Standard errors (in parentheses) are clustered at the study level. Significance levels are $0.1(*)$, $0.05(* *)$, and $0.01(* * *)$. 
Table B.2: Empirical studies included in meta-regression analysis

\begin{tabular}{|c|c|c|c|c|}
\hline \multirow[t]{2}{*}{ Study } & \multicolumn{2}{|c|}{ Model specifics } & \multicolumn{2}{|l|}{ Data } \\
\hline & Theoretical model & Empirical specification & Characteristics & Period \\
\hline Field and Grebenstein (1980) & long-run, conditional & structural, exogenous wage, no $\mathrm{FE}$ & industry-level, cross-section, admin & 1971 \\
\hline Denny et al. (1981) & long-run, conditional & structural, exogenous wage, no $\mathrm{FE}$ & firm-level, time-series, admin & $1952-1976$ \\
\hline Grant and Hamermesh (1981) & long-run, conditional & structural, exogenous wage, no FE & industry-level, cross-section, admin & 1969 \\
\hline Atkinson and Halvorsen (1984) & long-run, conditional & structural, exogenous wage, no FE & firm-level, cross-section, survey & 1970 \\
\hline Nissim (1984) & short-/intermediate-run, conditional & structural-form, endogenous wage, no FE & industry-level, time-series, admin & 1963-1978 \\
\hline Symmons and Layard (1984) & long-run, unconditional & reduced-form, en-/exogenous, no FE & industry-level, time-series, admin & $1956-1980$ \\
\hline Mairesse and Dormont (1985) & short-run, unconditional & reduced-form, exogenous wage, $\mathrm{FE}$ & firm-level, panel, survey & $1970-1979$ \\
\hline Allen 1986, & long-run, conditional & structural-form, exogenous wage, no FE & firm-level, cross-section, survey & $1972 / 1974$ \\
\hline Halvorsen and Smith (1986) & long-run, conditional & structural-form, exogenous wage, no FE & industry-level, time-series, admin & 1954-1974 \\
\hline Kokkelenberg and Choi 1986. & long-run, conditional & structural-form, exogenous wage, no $\mathrm{FE}$ & firm-level, cross-section, admin & 1970 \\
\hline Wadhwani (1987) & long-run, unconditional & reduced-form, exogenous wage, no $\mathrm{FE}$ & industry-level, time-series, admin & $1962-1981$ \\
\hline Kim 1988) & long-run, (un)conditional & structural-form, exogenous wage, no FE & industry-level, time-series, admin & $1948-1971$ \\
\hline Morrison 1988) & short-/intermediate-/long-run, conditional & structural, endogenous wage, no FE & industry-level, time-series, admin & $1955-1981$ \\
\hline Pencavel and Holmlund 1988. & short-/intermediate-/long-run, uncondition & ll reduced-form, endogenous wage, no $\mathrm{FE}$ & industry-level, time-series, admin & $1951-1983$ \\
\hline Wadhwani and Wall (1990) & short-run, unconditional & reduced-form, endogenous wage, $\mathrm{FE}$ & industry-level, panel, survey & 1974-1982 \\
\hline Arellano and Bond (1991) & short-/long-run, unconditional & reduced-form, ex/endogenous wage, (no) FE & firm-level, panel, survey & 1979-1984 \\
\hline
\end{tabular}


Table B.2: continued

\begin{tabular}{|c|c|c|c|c|}
\hline \multirow[t]{2}{*}{ Study } & \multicolumn{2}{|c|}{ Model specifics } & \multicolumn{2}{|l|}{ Data } \\
\hline & Theoretical model & Empirical specification & Characteristics & Period \\
\hline Griffin 1992, & long-run, conditional & structural-form, exogenous wage, no FE & firm-level, cross-section, survey & 1980 \\
\hline Dunne and Roberts (1993). & long-run, conditional & reduced-form, exogenous wage, (no) $\mathrm{FE}$ & firm-level, panel, survey & 1975-1981 \\
\hline Wolfson 1993) & short-run, conditional & structural-form, endogenous wage, $\mathrm{FE}$ & firm-level, panel, survey & 1976-1984 \\
\hline Fitzroy and Funke (1994) & short-run, conditional & reduced-form, endogenous wage, $\mathrm{FE}$ & industry-level, panel, admin & $1979-1990$ \\
\hline$?$ & short-/intermediate-run, conditional & reduced-form, endogenous wage, fixed effects & firm-level, panel, admin & 1989-1994 \\
\hline Konings and Vandenbussche (1995) & long-run, conditional & reduced-form, endogenous wage, $\mathrm{FE}$ & firm-level, panel, survey & $1982-1989$ \\
\hline Lindquist 1995) & intermediate, conditional & structural-form, exogenous wage, $\mathrm{FE}$ & firm-level, panel, admin & $1972-1990$ \\
\hline Draper and Manders (1997) & long-run, conditional & structural-form, endogenous wage, no FE & industry-level, time-series, admin & 1972-1993 \\
\hline Griffin (1996) & long-run, conditional & structural-form, exogenous wage, no FE & firm-/industry-level, cross-section, survey & 1980 \\
\hline Terrell (1996) & long-run, conditional & structural-form, exogenous wage, no FE & industry-level, time-series, admin & $1947-1971$ \\
\hline Cahuc and Dormont (1997) & short-/intermediate-run, conditional & reduced-form, exogenous wage, (no) $\mathrm{FE}$ & firm-level, panel, survey & $1986-198$ \\
\hline Falk and Koebel (1997) & long-run, conditional & structural-form, exogenous wage, no FE & industry-level, panel, admin & $1977-199$ \\
\hline Revenga (1997) & intermediate-run, (un)conditional & reduced-form, exogenous wage, (no) $\mathrm{FE}$ & firm-/industry-level, panel, survey & $1984-1990$ \\
\hline VanReenen (1997) & short-run, unconditional & reduced form, ex/endogenous wage, $\mathrm{FE}$ & firm-level, panel, admin & $1976-198$ \\
\hline Blechinger et al. (1998) & long-run, conditional & structural-form, exogenous wage, $\mathrm{FE}$ & firm-level, panel, survey & 1993-1995 \\
\hline FitzRoy and Funke (1998) & short-run, conditional & reduced form, endogenous wage, $\mathrm{FE}$ & industry-level, panel, admin & 1991-1993 \\
\hline
\end{tabular}


Table B.2: continued

\begin{tabular}{|c|c|c|c|c|}
\hline \multirow[t]{2}{*}{ Study } & \multicolumn{2}{|c|}{ Model specifics } & \multicolumn{2}{|l|}{ Data } \\
\hline & Theoretical model & Empirical specification & Characteristics & Period \\
\hline Hatzius (1998) & long-run, conditional & reduced-form, ex/endogenous wage, $\mathrm{FE}$ & firm-level, panel, survey & 1974-1994 \\
\hline Hine and Wright 1998) & short-run, conditional & reduced-form, exogenous wage, $\mathrm{FE}$ & industry-level, panel, admin & 1979-1992 \\
\hline Koebel (1998) & long-run, conditional & structural-form, exogenous wage, no FE & industry-level, panel, admin & 1960-1992 \\
\hline Milner and Wright (1998) & short-run, conditional & reduced-form, exogenous wage, $\mathrm{FE}$ & industry-level, panel, admin & 1972-1992 \\
\hline Roberts and Skoufias 1998, & long-run, conditional & reduced-form, exogenous wage, (no) $\mathrm{FE}$ & firm-level, panel, survey & 1981-1987 \\
\hline Rottmann and Ruschinski (1998) & short-run, conditional & reduced-form, exogenous wage, $\mathrm{FE}$ & firm-level, panel, survey & 1980-1992 \\
\hline Abraham and Konings 1999 & intermediate-run, conditional & reduced-form, exogenous wage, no FE & firm-level, panel, survey & $1990-1995$ \\
\hline \begin{tabular}{|l|l|} 
Allen and Urga 1999. \\
\end{tabular} & short-/long-run, conditional & structural-form, exogenous wage, no FE & industry-level, time-series, admin & $1965-1992$ \\
\hline Bellmann et al. (1999) & intermediate-run, conditional & structural-form, exogenous wage, no $\mathrm{FE}$ & firm-level, cross-section, admin & 1995 \\
\hline Blechinger and Pfeiffer (1999) & long-run, conditional & reduced-form, exogenous wage, $\mathrm{FE}$ & firm-level, panel, survey & 1992-1995 \\
\hline Falk and Koebel 1999) & long-run, conditional & structural-form, exogenous wage, $\mathrm{FE}$ & industry-level, panel, admin & 1978-1999 \\
\hline Funke et al. 1999) & short-run, conditional & reduced-form, endogenous wage, $\mathrm{FE}$ & firm-level, panel, admin & 1987-1994 \\
\hline Greenaway et al. 1999. & short-run, conditional & reduced-form, exogenous wage, $\mathrm{FE}$ & industry-level, panel, admin & $1979-1991$ \\
\hline Bellmann and Schank 2000 & intermediate-run, conditional & structural-form, exogenous wage, no FE & firm-level, cross-section, admin & 1995 \\
\hline \begin{tabular}{|l|l|} 
Braconier and Ekholm 2000) \\
\end{tabular} & long-run, conditional & reduced-form, exogenous wage, $\mathrm{FE}$ & firm-level, panel, survey & 1970-1994 \\
\hline Addison and Texeira (2001) & long-run, conditional & reduced-form, exogenous wage, no $\mathrm{FE}$ & industry-level, time-series, admin & $1977-1997$ \\
\hline
\end{tabular}


Table B.2: continued

\begin{tabular}{|c|c|c|c|c|}
\hline \multirow[t]{2}{*}{ Study } & \multicolumn{2}{|c|}{ Model specifics } & \multicolumn{2}{|l|}{ Data } \\
\hline & Theoretical model & Empirical specification & Characteristics & Period \\
\hline Falk 2001) & intermediate-run, conditional & reduced-form, exogenous wage, $\mathrm{FE}$ & firm-level, panel, survey & 1995-1997 \\
\hline Falk and Koebel (2001) & short-/intermediate-run, conditional & structural-form, exogenous wage, $\mathrm{FE}$ & industry-level, panel, admin & 1976-1995 \\
\hline 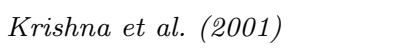 & intermediate-run, unconditional & reduced-form, ex/endogenous wage, $\mathrm{FE}$ & firm-level, panel, admin & 1983-1986 \\
\hline Slaughter (2001) & intermediate-run, unconditional & reduced-form, exogenous wage, $\mathrm{FE}$ & industry-level, panel, admin & 1961-1991 \\
\hline Bellmann et al. 2002) & intermediate-run, conditional & structural-form, exogenous wage, no $\mathrm{FE}$ & firm-level, panel, admin & 1993-1998 \\
\hline Falk and Koebel 2002, & intermediate-run, conditional & structural-form, exogenous wage, $\mathrm{FE}$ & industry-level, panel, admin & 1978-1990 \\
\hline Koebel 2002, & long-run, conditional & structural-form, exogenous wage, $\mathrm{FE}$ & industry-level, panel, admin & $1978-1990$ \\
\hline Bruno et al. (2003) & short-/long-run, conditional & reduced-form, exogenous wage, $\mathrm{FE}$ & industry-level, panel, admin & 1970-1996 \\
\hline Koebel et al. 2003) & long-run, conditional & structural-form, exogenous wage, $\mathrm{FE}$ & industry-level, panel, admin & 1978-1990 \\
\hline Barba Navaretti et al. (2003) & short-run, conditional & reduced-form, exogenous wage, $\mathrm{FE}$ & firm-level, panel, survey & $1993-2000$ \\
\hline Ogawa 2003. & short-run, conditional & reduced-form, endogenous wage, $\mathrm{FE}$ & firm-level, panel, survey & 1993-1998 \\
\hline Bernal and Cardenas 2004) & short-run, conditional & reduced-form, ex/endogenous, (no) $\mathrm{FE}$ & firm-/industry-level, panel, survey & 1978-1991 \\
\hline Cassoni et al. 2004) & short-/long-run, conditional & structural-/reduced-form, ex/endogenous, $\mathrm{FE}$ & industry-level, panel, admin & 1975-1997 \\
\hline Falk and Koebel 2004) & intermediate-run, conditional & structural-form, exogenous wage, $\mathrm{FE}$ & industry-level, panel, admin & 1978-1994 \\
\hline Konings and Murphy (2004) & short-/long-run, conditional & reduced-form, exogenous wage, $\mathrm{FE}$ & firm-level, panel, survey & 1993-1998 \\
\hline Mondino and Montoya (2004) & short-run, conditional & reduced-form, ex/endogenous wage, $\mathrm{FE}$ & firm-level, panel, survey & 1990-1996 \\
\hline
\end{tabular}


Table B.2: continued

\begin{tabular}{|c|c|c|c|c|}
\hline \multirow[t]{2}{*}{ Study } & \multicolumn{2}{|c|}{ Model specifics } & \multicolumn{2}{|l|}{ Data } \\
\hline & Theoretical model & Empirical specification & Characteristics & Period \\
\hline Saavedra and Torero (2004) & short-/long-run, conditional & reduced-form, exogenous wage, (no) FE & firm-/industry-level, panel, survey & 1987-1997 \\
\hline Addison and Texeira 2005) & short-/long-run, (un)conditional & reduced-form, endogenous wage, (no) $\mathrm{FE}$ & firm-/industry-level, panel/time-series, & n 1977-2001 \\
\hline Amiti and Wei 2005, & short-/long-run, (un)conditional & reduced-form, exogenous wage, $\mathrm{FE}$ & industry-level, panel, admin & 1995-2001 \\
\hline Arnone et al. 2005, & short-run, (un)conditional & reduced-form, endogenous wage, $\mathrm{FE}$ & firm-level, panel, survey & 1998-2002 \\
\hline Basu et al. (2005) & short-/long-run, conditional & reduced-form, endogenous wage, $\mathrm{FE}$ & firm-level, panel, admin & 1989-1993 \\
\hline Becker et al. 2005) & intermediate-run, conditional & structural-form, exogenous wage, no FE & firm-level, cross-section, admin/survey & $1998 / 2000$ \\
\hline Bruno and Falzoni (2005) & short-/long-run, conditional & reduced-form, ex/endogenous wage, $\mathrm{FE}$ & industry-level, panel, admin & 1970-1997 \\
\hline Fajnzylber and Maloney 2005, & long-run, unconditional & reduced-form, endogenous wage, $\mathrm{FE}$ & firm-level, panel, survey & 1977-1995 \\
\hline Falk and Wolfmayr 2005, & long-run, conditional & reduced-form, exogenous wage, $\mathrm{FE}$ & industry-level, panel, admin & $1995-2000$ \\
\hline Fu and Balasubramanyam 2005, & short-run, conditional & reduced-form, exogenous wage, $\mathrm{FE}$ & industry-level, panel, survey & 1987-1998 \\
\hline Görg and Hanley 2005). & short-run, conditional & reduced-form, ex/endogenous, $\mathrm{FE}$ & firm-level, panel, survey & 1990-1995 \\
\hline Hijzen et al. 2005, & intermediate-run, conditional & structural-form, exogenous wage, (no) FE & industry-level, panel, survey & 1982-1996 \\
\hline Amiti and Wei 2006, & short-/intermediate-run, (un)conditional & reduced-form, exogenous wage, $\mathrm{FE}$ & industry-level, panel, admin & $1992-2000$ \\
\hline Bellmann and Pahnke (2006) & short-run, conditional & reduced-form, exogenous wage, $\mathrm{FE}$ & firm-level, panel, admin & 1996-2004 \\
\hline Blien et al. (2006) & short-/intermediate-run, conditional & reduced-form, exogenous wage, $\mathrm{FE}$ & firm-level, panel, admin & 1993-2002 \\
\hline Ekholm and Hakkala (2006) & intermediate, conditional & structural-form, exogenous wage, no $\mathrm{FE}$ & industry-level, panel, admin & 1995-2000 \\
\hline
\end{tabular}


Table B.2: continued

\begin{tabular}{|c|c|c|c|c|}
\hline \multirow[t]{2}{*}{ Study } & \multicolumn{2}{|c|}{ Model specifics } & \multicolumn{2}{|l|}{ Data } \\
\hline & Theoretical model & Empirical specification & Characteristics & Period \\
\hline Koebel (2006) & long-run, conditional & structural-form, exogenous wage, FE & industry-level, panel, admin & 1976-1995 \\
\hline \begin{tabular}{|l|l|} 
Harrison and McMillan 2006. \\
\end{tabular} & intermediate-run, (un)conditional & structural-/reduced-form, exogenous wage, $\mathrm{F}$ & firm-level, panel, survey & 1982-1999 \\
\hline Crino (2007) & intermediate-run, conditional & structural-form, ex/endogenous wage, FE & industry-level, panel, admin & 1990-2004 \\
\hline Haouas and Yagoubi (2007) & intermediate-run, unconditional & reduced-form, exogenous wage, (no) $\mathrm{FE}$ & industry-level, panel, admin & 1971-1996 \\
\hline Hasan et al. (2007) & intermediate-run, conditional & reduced-form, exogenous wage, $\mathrm{FE}$ & industry-level, panel, survey & 1980-1997 \\
\hline Lachenmaier and Rottmann 2007 & long-run, conditional & exogenous wage, $\mathrm{FE}$ & firm-level, panel, survey & $1982-2003$ \\
\hline Molnar and Taglioni (2007) & short-/long-run, conditional & reduced-form, ex/endogenous, $\mathrm{FE}$ & industry-level, panel, admin & 1993-2003 \\
\hline Aguilar and Rendon 2008. & long-run, unconditional & reduced-form, ex/endogenous wage, no FE & firm-level, cross-section, survey & 2004 \\
\hline Jacobi and Schaffner 2008) & intermediate-run, conditional & structural-form, exogenous wage, $\mathrm{FE}$ & industry-level, panel, admin & $1999-2005$ \\
\hline 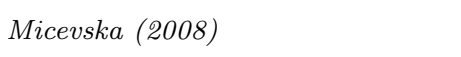 & short-run, conditional & reduced-form, exogenous wage, $\mathrm{FE}$ & firm-level, panel, admin & 1994-1999 \\
\hline Onaran 2008 & short-/long-run, conditional & reduced-form, ex/endogenous wage, $\mathrm{FE}$ & industry-level, panel, admin & 1999-2004 \\
\hline Görg et al. 2009 & short-run, conditional & reduced-form, ex/endogenous wage, (no) FE & firm-level, panel, survey & 1983-1998 \\
\hline Godart et al. 2009) & short-run, conditional & reduced-form, exogenous wage, (no) $\mathrm{FE}$ & firm-level, panel, survey & $1997-2005$ \\
\hline Aguilar and Rendon 2010. & long-run, unconditional & reduced-form, ex/endogenous wage, no FE & firm-level, cross-section, survey & 2004 \\
\hline Brixy and Fuchs 2010) & short-run, conditional & reduced-form, exogenous wage, $\mathrm{FE}$ & firm-level, panel, survey & 2001-2006 \\
\hline Buch and Lipponer (2010) & short-run, conditional & reduced-form, endogenous wage, $\mathrm{FE}$ & firm-level, panel, survey & 1997-2004 \\
\hline
\end{tabular}


Table B.2: continued

\begin{tabular}{|c|c|c|c|c|}
\hline \multirow[t]{2}{*}{ Study } & \multicolumn{2}{|c|}{ Model specifics } & \multicolumn{2}{|c|}{ Data } \\
\hline & Theoretical model & Empirical specification & Characteristics & Period \\
\hline Freier and Steiner 2010, & intermediate-run, conditional & structural-form, exogenous wage, $\mathrm{FE}$ & industry-level, panel, admin & 1999-2003 \\
\hline Hakkala et al. 2010) & short-run, conditional & reduced-form, endogenous wage, $\mathrm{FE}$ & firm-level, panel, admin & 1990-2002 \\
\hline Hijzen and Swaim (2010) & intermediate-run, (un)conditional & reduced-form, ex/endogenous wage, $\mathrm{FE}$ & industry-level, panel, admin & 1980-2002 \\
\hline Senses 2010) & intermediate-run, conditional & structural-form, exogenous wage, $\mathrm{FE}$ & firm-level, panel, survey & 1972-2001 \\
\hline Bohachova et al. (2011) & short-run, conditional & reduced-form, ex/endogenous wage, (no) FE & firm-level, panel, survey & $2000-2008$ \\
\hline Mitra and Shin (2011) & intermediate-run, (un)conditional & reduced-form, exogenous wage, (no) $\mathrm{FE}$ & firm-level, panel survey & $2002-2008$ \\
\hline Ayala 2012, & short-run, (un)conditional & reduced-form, ex/endogenous wage, $\mathrm{FE}$ & industry-level, panel, survey & 1974-2009 \\
\hline Crino (2012) & intermediate-run, conditional & structural-form, exogenous wage, $\mathrm{FE}$ & industry-level, panel, admin & 1990-2004 \\
\hline Kölling (2012), & intermediate-run, conditional & structural-form, exogenous wage, $\mathrm{FE}$ & firm-level, panel, survey & $2000-2007$ \\
\hline
\end{tabular}

